\title{
The Foundations of Financial Inclusion: Understanding Ownership and Use of Formal Accounts
}

\author{
Franklin Allen, Asli Demirguc-Kunt, Leora Klapper, and Maria Soledad Martinez Peria*
}

\begin{abstract}
Financial inclusion-defined as the use of formal accounts - can bring many benefits to individuals. Yet, we know very little about the factors underpinning it. This paper explores the individual and country characteristics associated with financial inclusion and the policies that are effective among those most likely to be excluded: poor, rural, female or young individuals. Overall, we find that greater financial inclusion is associated with lower account costs, greater proximity to financial intermediaries, stronger legal rights, and more politically stable environments. However, the effectiveness of policies to promote inclusion varies depending on the characteristics of the individuals considered.
\end{abstract}

JEL: D14, G21, G28

Keywords: Household Finance; Financial Institutions; Government Policy and Regulation

\footnotetext{
* Allen is the Executive Director of the Brevan Howard Centre and Professor of Finance and Economics at Imperial College London. He is on leave from the Wharton School of the University of Pennsylvania (e-mail: allenf@wharton.upenn.edu); Demirguc-Kunt (e-mail: Ademirguckunt@worldbank.org), Klapper (e-mail: lklapper@worldbank.org), and Martinez Peria (e-mail: Mmartinezperia@worldbank.org) are in the Development Research Group, World Bank. Peter Van Oudheusden provided excellent research assistance. We are grateful for research funding from the Bill \& Melinda Gates Foundation and the World Bank Research Support Budget. We thank Mary Hallward-Driemeier, Aart Kraay, Douglas Randall, Douglas Pearce, and seminar participants at the World Bank, the CEPR/Study Center Gerzensee European Summer Symposium in Financial Markets, and the FDIC's $2^{\text {nd }}$ Annual Consumer Research Symposium for helpful comments. This paper's findings, interpretations, and conclusions are entirely those of the authors and do not necessarily represent the views of the World Bank, the Executive Directors, or the countries they represent.
} 


\section{Introduction}

Financial inclusion, typically defined as the use of formal financial services, has become a subject of growing interest among researchers, policy makers, and other financial sector stakeholders. For instance, G20 leaders have committed and ramped up their efforts to meet the challenge of promoting financial inclusion around the world (GPFI, 2015). A growing body of research has focused on the beneficial effects for individuals, providing both an economic and a political rationale for government policies to promote financial inclusion. In particular, the evidence is most compelling when it comes to the use of bank accounts. Having a bank account increases savings (Aportela, 1999), female empowerment (Ashraf et al., 2010), and consumption and productive investment of entrepreneurs (Dupas and Robinson, 2009).

In addition, previous studies focusing on the unbanked in the US have argued that not having a bank account can have a wide range of harmful effects. For instance, the lack of a bank account can make liquidity management and payments difficult, which could result in high fees associated with the use of money orders or check-cashing services (Lusardi, 2010). Also, cash transactions present financial and personal risks for those unbanked, since individuals have no recourse if the funds are stolen (Gross, Hogarth and Schmeiser, 2012). Moreover, an individual's decision to remain unbanked can have long-lasting effects, since having a bank account can facilitate asset building and wealth creation that may allow for consumption smoothing at retirement or when faced with shocks (Rhine et al., 2006).

Despite evidence on the importance of financial inclusion, little is known about its underpinnings across individuals and countries and about the policies that foster inclusion. ${ }^{1}$ Existing cross-country studies rely on country level proxies (such as the number of bank accounts

\footnotetext{
${ }^{1}$ The exception is the US, where a sizeable literature studies the unbanked and their behavior. See, for example, Barr (2004), Hogarth et al. (2004,2005), Rhine and Greene (2006), Rhine et al. (2006) and Gross et al. (2012).
} 
per capita), drawing on data collected from bank regulators and supervisors (Beck, DemirgucKunt, and Martinez Peria, 2007; Honohan, 2008; Kendall, Mylenko, and Ponce, 2010). Not only are these studies problematic because the proxies used have significant limitations, such as individuals with multiple accounts and foreign-owned accounts, but more importantly, the fact that data collected from providers of financial services are aggregated at the country level makes it impossible to assess how the impact of policies varies across individual characteristics, such as income, gender, location, or age.

At the household or individual level, there is a growing literature on specific interventions that can foster the use of financial instruments to save. In particular, field experiments, following a randomized controlled trial (RCTs) methodology, have examined the impact of commitment devices (Ashraf et al., 2006), reminders (Karlan et al., 2010), temporary saving subsidies (Schaner, 2013), and peer pressure (Kast et al., 2012) as some of the ways to promote the use of accounts. While the randomized design of the interventions analyzed in these studies should in principle allow for a clean method to identify the average effect of the treatment, there are various concerns with the use of RCTs to answer broad questions in development (Deaton, 2009). First, typically RCTs cannot be used to study the impact of macroeconomic policies and institutional country features. Second, it is doubtful that RCTs conducted in a particular setting can be applied in a different setting. That is, RCTs might lack external validity (Rodrik, 2008). As Rodrik argues "evidence from randomized field experiments need not be more informative than other types of evidence which may have less airtight causal identification but are stronger on external validity (because of broader geographical or temporal coverage).”

This paper uses the first comparable global database of financial inclusion indicators: Global Findex. The data was collected by Gallup, Inc. (in conjunction with the Gallup World Poll 
survey) and based on interviews with over 150,000 randomly selected adults in over 140 countries. ${ }^{2}$ Using the Global Findex data, our paper not only examines the extent to which different individual characteristics and country level variables and policies are associated with financial inclusion, but also exploits the unique individual level nature of the data to investigate how the factors and policies associated with greater inclusion vary according to individual level characteristics. In particular, we are interested in analyzing whether policies to promote inclusion are especially effective among the most commonly excluded (and hence targeted) groups of individuals: the poor, those living in rural areas, females, and young individuals. For those who are financially excluded, we also investigate how the perceived barriers to inclusion (as reported by the individuals) correlate with individual and country characteristics, as well as policy measures.

While most formal financial institutions offer an array of financial services, we focus on deposit account use for several reasons. First, ownership of an account is typically comparable across countries, in contrast with credit, which varies by maturity, interest, collateral requirements, and the like. Second, deposit accounts provide mechanisms for both payments and savings, which are likely to be more universally demanded than credit. In their research on the financial lives of poor households, for example, Collins et al. (2009) find a pattern of intensive use of savings instruments. Third, even if we assume that 100 percent of the population demands credit, it is clear that not everyone is deserving of credit. Many individuals might not have good investment projects, so it would be inefficient to allocate resources to these individuals. Finally, financial stability concerns might imply that universal use of credit services may not be a policy goal. The recent U.S. subprime crisis illustrates this issue very clearly. On the other hand, assuming that

\footnotetext{
2 All sampling, surveying methodology, and data quality checks are harmonized across countries. For more information see http://www.gallup.com/strategicconsulting/en-us/worldpoll.aspx).
} 
there is universal demand for deposit, savings, and payment services, there are a priori fewer reasons why striving for 100 percent inclusion for basic account use would have major negative implications for financial stability.

We analyze the underpinnings of three indicators of account use: (i) ownership of an account, (ii) use of the account to save, and (iii) frequent use of the account (defined as three or more withdrawals per month). Overall, we find that financial inclusion is associated with lower account costs, greater proximity to financial intermediaries, stronger legal rights and more politically stable environments. However, the effectiveness of policies to promote inclusion varies depending on the characteristics of the individuals considered. Finally, among those who do not have accounts, we analyze the factors associated with self-reported barriers to inclusion and find that these individuals report lower barriers in countries with lower costs of accounts and greater penetration of financial service providers. In addition, we find that among those that report lack of money as the main barrier to account use, government policies to promote inclusion can increase the likelihood that individuals perceive financial services as being within their reach.

The rest of the paper is organized as follows. Section 2 summarizes our main variables of interest. Section 3 details the empirical approach we follow to test the underpinnings of the use of accounts and the factors correlated with perceived barriers to account use. Section 4 presents the empirical results. Section 5 concludes.

\section{Measuring financial inclusion}

From the 2011 Global Findex database, described in Demirguc-Kunt and Klapper (2013), we use data for 123 countries and over 124,000 individuals. We drop data for 25 countries because of missing demographic information, such as education and income. Table 1 lists all countries 
included in our sample. ${ }^{3}$ We use these data to calculate our measures of account use. Below, we provide precise definitions (Table 2) and summary statistics for each of these indicators (Table 3).

\section{Account Ownership}

To calculate account ownership, we use the question: "Do you, either by yourself or together with someone else, currently have an account at a bank, credit union, cooperative, post office, or microfinance institution? An account can be used to save money, to make or receive payments, or to receive wages and remittances." On average, 45 percent of adults in our sample of countries report having an account. ${ }^{4}$ Not surprisingly, there is enormous variation in the use of financial services between high-income and developing economies: account penetration is close to universal (91 percent) in high-income economies, while only 41 percent of adults in developing economies, on average, report having an account at a formal financial institution. Furthermore, we find that among developing economies, account ownership, on average, increases sharply with economic development (Figure 1): adults in upper-middle-income countries (58 percent) are almost three times as likely to have an account as adults in low-income economies (19 percent).

In addition to sharp differences in account penetration across countries, there are also important disparities in account use by individual characteristics. For example, among developing countries in our sample, those in the highest within-country income quintile are more than twice as likely to have an account as those in the lowest income quintile. There are also significant disparities in the prevalence of accounts along gender lines: in developing countries in our sample, 46 percent of men report having an account at a formal financial institution, compared to 37 percent

\footnotetext{
${ }^{3}$ Individual level data are available at: http://www.worldbank.org/globalfindex.

${ }^{4}$ All statistics aggregated above the country level (by income group, region, and the like) use population weights in addition to individual-level weights.
} 
of women. In developing economies, adults with a tertiary education are, on average, more than twice as likely to have an account as those with a primary education or less. Furthermore, in both high-income and developing economies, adults between the ages of 25 and 64 are more likely to report having an account at a formal financial institution than younger adults and those aged 65 and over. Finally, the urban/rural divide also figures prominently in the prevalence of bank accounts in the developing world. While close to 50 percent of adults in cities have an account, the figure is less than 40 percent among individuals in rural areas.

\section{The use of accounts to save}

In addition to account ownership, we are interested in the use of accounts to save. This information is provided in the question: "In the past 12 months, have you saved or set aside any money?" If the respondent answered yes, a follow-up question asked, "In the past 12 months, have you saved or set aside money by: A) Using an account at a bank, credit union, microfinance institution, or another financial institution". Among those individuals who have an account (that is, conditional on having an account), 42 percent of adults, on average, used the account to save in the past year. Unlike what we found in regard to account penetration, we find small differences between the average share of individuals who use an account to save in developed countries (49 percent) and those who do so in low- and middle-income countries (40 percent) (Figure 1). In other words, globally, adults who have a formal account are on average about equally likely to use their account to save. In addition to having an account, formal saving is also conditional on an individual's ability and willingness to save. This may be associated with cyclical macroeconomic conditions, idiosyncratic shocks (such as illness or unemployment), as well as cultural attitudes 
toward saving. An important caveat is that the data were collected in 2011, following the global financial crisis, which might have affected individuals' ability to save.

In terms of differences across individuals in the share of adults who use their account to save, we find that there are practically no differences between males and females. Also, we do not find large differences between individuals in rural and urban areas. In fact, within developing countries in our sample, we find few differences across individual level characteristics. In general, conditional on having an account, between 30 and 50 percent of individuals in developing countries use the account to save. In contrast, in developed countries we observe significant differences in the share of individuals who use their account to save across income quintiles and across different levels of education.

\section{The frequency of account use}

Beyond the simple ownership of bank accounts, another measure of account "usage" is the frequency of account use. In our estimations, we focus on withdrawals, since such actions are actively initiated by account holders whereas deposits might be initiated by others (for example, employers or governments). The questionnaire asks account holders: "In a typical month, about how many times is money taken out of your personal account(s)? This includes cash withdrawals, electronic payments or purchases, checks, or any other time money is removed from your account(s) by yourself or others." Respondents are asked (categorically) if they conducted (a) zero withdrawals, (b) 1-2 withdrawals, (c) 3-5 withdrawals, or (d) 6 or more withdrawals in a typical month. In developing countries, 18 percent of individuals who have an account never withdraw funds during the course of a month. This number is only 4 percent in developed countries. Similarly, while 58 percent of individuals in developing countries withdraw funds from their 
accounts one or two times a month (most likely when they receive their salaries), the corresponding figure is 22 percent among individuals in high-income countries.

Adults who report one to two withdrawals in a typical month may have an account to receive wages, government payments, or money from family living elsewhere, and likely withdraw the complete amount when payments are deposited. Or barriers to accessing their account, such as high withdrawal fees or long distances to the nearest bank, may discourage the use of accounts for day-to-day cash management. In comparison, those who withdraw from their account more than three times in a typical month are more likely to use their account to store cash or make formal electronic payments.

We define frequent use of an account as a dummy that takes the value 1 if funds are withdrawn at least three times during a month. As shown in Figure 1, on average, adults in highincome economies are more than three times as likely to withdraw funds frequently (i.e., three or more times a month), compared with adults in low- and middle-income countries. Within our sample of countries, 72 percent of individuals in high-income countries use their account frequently, while only 22 percent do so in developing countries. Within countries, account use appears to be more frequent among richer and among more educated individuals. In developing countries, individuals in urban areas are almost twice as likely to use their accounts frequently.

\section{Reported barriers to account ownership}

The survey also provides some insights into barriers to inclusion: over 65,000 adults with no formal account were asked why they do not have an account at a financial institution. Globally, the most cited reason for not having a bank account is "[I] don't have enough money to use them." This reason was reported by 66 percent of adults without a formal account, including 30 percent 
who reported this as the only reason (multiple responses were permitted). This segment of the population is more likely to be "voluntarily" self-excluded from the formal financial system - that is, individuals who do not have sufficient cash earnings to need the use of a formal account or who choose not to have an account for cultural or religious reasons. For example, "because of religious reasons" was cited by 5 percent of adults. Another reason cited for not having an account is "someone else in the family already has an account," which identifies the group of indirect users (23 percent).

Yet there may also be individuals who are "involuntarily" excluded, who do not use formal financial services because of barriers (such as distance or high cost) that arise as a result of market failures (such as asymmetric information or inadequate contract environment). Indeed, the second most important reason reported for not having an account is "[banks/accounts] are too expensive" (24 percent). Other reported reasons, by order of importance, are: "[banks] are too far away" (20 percent); "[I] don't have the necessary documentation" (17 percent); and "[I] don't trust [banks]" (13 percent). The role of policy is to broaden financial inclusion to reach those who are excluded because of barriers and market failures.

Although an analysis of self-reported barriers cannot support causal statements, the data can help suggest potential policies for expanding account use. For example, a commonly cited reason for not having an account is affordability. Fixed transactions costs and annual fees tend to make small transactions unaffordable for large parts of the population. To maintain a checking account in Sierra Leone, for example, an adult must pay the equivalent of 27 percent of that country's GDP per capita in annual fees (Beck et al., 2008), which is likely a reason why 44 percent of non-account-holders in that country cited cost as a reason for not having a formal account. But 
fixed fees and high costs of opening and maintaining accounts also often reflect lack of competition and underdeveloped physical or institutional infrastructure.

A second important barrier is documentation requirements. By limiting eligibility, these may exclude workers in the rural or informal sectors, who are less likely to have wage slips or formal proof of domicile. Because of legitimate concerns about fraud and money laundering, however, there is a reasonable limit to how much documentation requirements should be relaxed, and this line likely varies across countries.

Another important barrier to formal account ownership is proximity to a bank. For example, 47 percent of non-account-holders in Tanzania reported distance as a reason why they don't have an account and Tanzania also ranks near the bottom among developing economies in bank branch penetration by area, averaging less than 0.5 bank branches per 1,000 square kilometers.

Trust in banks—or distrust—can constitute a barrier that is difficult to overcome, and suggested causes have been linked to cultural norms, local governance, economic crises, and uncertainty about the future (Bjornskov, 2007; Guiso et al., 2004; Sapienza and Zingales, 2011). For example, respondents in the former Soviet Union — which has been plagued by episodes of government expropriation of bank assets - were almost three times as likely as adults in other regions to choose “[I] don’t trust banks" (31 percent).

These self-reported barriers and the information gathered by the survey on account use raise the following questions, which we can test econometrically: First, do we continue to find a significant relationship between account ownership and use (as measured by high-frequency withdrawals and formal saving) and country level measures of cost, distance, and documentation, after controlling for individual characteristics? Second, do we find a significant relationship 
between government policies designed to promote financial inclusion and greater usage of formal financial services? Third, do our empirical results suggest that relaxing these constraints would have disproportionate effects on any individual subgroups, such as poor, female, young or rural residents? And fourth, are reasons reported by those excluded for not having an account related to these country characteristics? Below, we outline the econometric methodology we pursue to answer these questions.

\section{Empirical methodology}

\section{Baseline specifications}

Our main empirical specifications focus on three dimensions of the use of bank accounts: (a) owning a bank account, (b) using a bank account to save, and (c) using the bank account frequently (defined as three or more withdrawals per month). The dependent variable $y_{1 i j}$, account ownership, is a binary variable equal to 1 when an individual owns an account and 0 otherwise. Therefore, we use the following model to investigate its determinants:

$$
\begin{array}{ll}
y_{1 i j}^{*}=x_{1 i}^{\prime} \beta+z_{1 i j}^{\prime} \gamma+\varepsilon_{1 i j}, \\
y_{1 i j}=1 & \text { if } y_{1 i j}^{*}>0, \\
y_{1 i j}=0 & \text { if } y_{1 i j}^{*} \leq 0,
\end{array}
$$

where countries and individuals are indexed by $i$ and $j$, respectively; $y_{1 i j}^{*}$ is a latent variable, $x_{1 i}$ is a vector of country characteristics, $z_{1 i j}$ is a vector of individual level characteristics, $\beta$ and $\gamma$ are vectors of parameters, and $\varepsilon_{1 i j}$ is a normally distributed error term with zero mean and variance 
equal to 1 . We estimate (1) as a probit model by maximum likelihood. In some specifications, we replace $x_{1 i}$ with country fixed effects. ${ }^{5}$

Since we only observe whether an individual uses a bank account to save, $y_{2 i j}$, if he or she owns an account, estimating the use of accounts to save involves running a Heckman-style model (Heckman, 1979) where equation (1) above is the selection equation and equation (2) below captures individuals' decision to use their account to save: ${ }^{6}$

$$
\begin{array}{ll}
y_{2 i j}^{*}=x_{2 i}^{\prime} \beta_{2}+z_{2 i j}^{\prime} \gamma_{2}+\varepsilon_{2 i j}, \\
y_{2 i j}=1 & \text { if } y_{2 i j}^{*}>0, \\
y_{2 i j}=0 & \text { if } y_{2 i j}^{*} \leq 0,
\end{array}
$$

where $y_{2 i j}$, a dummy equal to 1 when an individual who has an account uses it to save, is observed only when $y_{1 i j}=1$. As before, countries and individuals are indexed by $i$ and $j$, respectively. $y_{2 i j}^{*}$ is a latent variable. $x_{2}$ and $z_{2}$ are the vectors of country and individual level variables, respectively. Their corresponding vectors of parameters are given by $\beta_{2}$ and $\gamma_{2}$. The error term $\varepsilon_{2 i j}$ is normally distributed with zero mean and variance equal to 1. Ideally, we would like to have at least a variable that explains individuals' decision to have an account but not their resolve to use the account to save. If that were the case, $x_{2}$ and/or $z_{2}$ would differ from $x_{1}$ and/or $z_{1}$ and we could identify the estimation of (1) and (2) with that exclusion restriction. However, in our case, we believe that we

\footnotetext{
${ }^{5}$ Our results are robust to the estimation of a logit model (available upon request).

${ }^{6}$ Since using an account to save is a binary variable to be estimated with a probit model, we cannot use Heckman's (1979) two-step estimation procedure. The inverse Mills ratio, or Heckman's lambda, only enters in the second step of this procedure in the case of a linear model; see Greene (2012, p. 880). Therefore, we jointly estimate the probit selection procedure and the probit model by maximum likelihood.
} 
cannot argue that such a variable exists and, hence, we follow Lemke and Reed (2001) and Marinescu (2007) in jointly estimating (1) and (2) by maximum likelihood. ${ }^{7}$

Similar to what we described for $y_{2 i j}$, using an account frequently (that is, three or more times a month), which we label $y_{3 i j}$, can only be observed as long as the individual owns an account. Hence, in order to analyze the determinants of using an account frequently, we run a sample selection model similar to that presented in equations (1) and (2), replacing $y_{2 i j}$ with $y_{3 i j}$ as the dependent variable and including $x_{3 i}$ and $z_{3 i j}$ as the vectors of country and individual level variables, respectively. As above, since in principle we have to assume that the variables that affect the likelihood of having an account $\left(x_{1 i}\right.$ and $\left.z_{1 i j}\right)$ are the same as those that affect the frequency of using an account $\left(x_{3 i}\right.$ and $\left.z_{3 i j}\right)$, we estimate the selection and frequency equations a la Heckman (but with two dichotomous dependent variables) using maximum likelihood.

In addition to analyzing how different individual and country characteristics relate to greater financial inclusion, we also examine reported subjective barriers to financial inclusion. We identify these barriers based on the respondents' answers to the following question: "Please tell me whether each of the following is a reason why you, personally, do not have an account at a bank, credit union, or other financial institution." The reasons we analyze are: "(a) They are too expensive"; "(b) You don't have the necessary documentation (ID, wage slip)"; "(c) They are too far away"; “(d) You don't trust them"; and “(e) You don't have enough money to use them.” The

\footnotetext{
${ }^{7}$ Sartori (2003) points out that the Heckman-type estimator may perform poorly when the same variables are included in both the selection (likelihood of having an account) and the outcome (likelihood of using the account to save) equations. This is especially problematic when estimations are conducted using small samples. Sartori (2003) proposes an alternative estimator that assumes that errors are near identical across equations to obtain more precise estimates. In unreported regressions, we applied the Sartori method. We found that the results based on the Sartori estimator are almost identical in size and in significance to those we obtain when using the probit Heckman-type model (without weights). Our challenge is that the Sartori estimator does not allow for the use of weights which is very important when using individiual level survey data. Hence, given the similarity of the results and considering that we have a large sample, we prefer to estimate the Heckman-type model with two binary dependent variables using maximum likelihood.
} 
respondents could name multiple reasons. For each of these reported reasons, we create a binary variable that takes the value 1 if a respondent without a bank account confirms it as a barrier to having an account and 0 otherwise. These dependent variables are denoted with $y_{5_{K} i j}$, where $K \in$ $\{a, b, c, d, e\}$. Given that these questions are only asked to individuals that do not own an account, we run a sample selection model similar to those estimated to analyze the use of accounts. However, in this case $y_{4 i j}$ takes the value of 1 if the respondent does not have an account. $x_{4 i}$ and $z_{4 i j}$ are included as the vectors of country and individual level variables, respectively. This results in the following model:

$$
\begin{aligned}
& y_{4 i j}^{*}=x_{4 i}^{\prime} \beta+z_{4 i j}^{\prime} \gamma+\varepsilon_{4 i j} \\
& y_{4 i j}=1 \quad \text { if } y_{4 i j}^{*}>0, \\
& y_{4 i j}=0 \quad \text { if } y_{4 i j}^{*} \leq 0, \\
& \text { which defines the probit selection procedure, and } \\
& y_{5_{K} i j}^{*}=x_{5 i}^{\prime} \beta_{K} \mathrm{k}+z_{5 i j}^{\prime} \gamma_{k}+\varepsilon_{5_{K} i j}, \quad K \in\{a, b, c, d, e\} \\
& y_{5_{K} i j}=1 \quad \text { if } y_{5_{K} i j}^{*}>0, \quad K \in\{a, b, c, d, e\} \\
& y_{5_{K} i j}=0 \quad \text { if } y_{5_{K} i j}^{*} \leq 0, \quad K \in\{a, b, c, d, e\}
\end{aligned}
$$

where countries and individuals are indexed by $i$ and $j$, respectively; $y_{5_{K} i j}^{*}$ is a latent variable, $x_{5 i}$ is a vector of country characteristics, $z_{5 i j}$ is a vector of individual level characteristics, $\beta$ and $\gamma$ are vectors of parameters, and $\varepsilon_{5_{K} i j}$ is a normally distributed error term with zero mean and variance equal to 1 , with $K \in\{a, b, c, d, e\}$. We estimate (3) and (4) by maximum likelihood assuming that $x_{4 i}=x_{5 i}$ and $z_{4 i}=z_{5 i}$.

\section{Explanatory variables}


Among the individual level characteristics in $z_{1 i j}, z_{2 i j}, z_{3 i j}$, and $z_{4 i j}$, we include a number of socioeconomic variables that we speculate might affect the use of bank accounts. All variables, summarized in Table 2, come from the Gallup World Poll (2012). Female indicates whether the respondent is a woman. To the extent that it is harder for women to have bank accounts, (perhaps because they are less likely to work or make independent financial decisions), we expect this variable to have a negative sign. Age and Age Squared are both in years. We expect the use of bank accounts to first increase and then decline with age, so in order to capture this we also include age squared.

Rural takes the value 1 if the respondent lives in a rural area and 0 otherwise, where a rural area is defined as a town or village with less than 50,000 inhabitants. If this information is not available, a rural classification is based on the interviewer's perception of whether a respondent lives in a rural area, on a farm, in a small town, or in a village. In general, the presence of financial institutions is more limited in rural areas, so we expect this variable to have a negative sign.

The Income Quintile variables are indicators of within-country relative income, based on the income of the respondents in a country. There are five such dummies (the top quintile is the excluded category in the regressions), which range from the poorest 20 percent to the richest 20 percent. Overall, we expect bank account use to be positively related to individuals' income.

Each respondent falls into one of three education categories, represented by three variables: 0-8 Years of Education corresponds to completion of elementary education or less, 9-15 Years of Education corresponds to completion of secondary education and some education beyond that, and > 15 Years of Education corresponds to four years of completed education after high school or completion of a four-year college degree. We expect the likelihood of account ownership to be positively associated with an individual's level of education. 
Married indicates whether a respondent is married, and Divorced/Separated indicates whether a respondent is divorced or separated. The variable Household Size (log) is the logarithm of household size, including the number of children in the household. We speculate that adults who live in larger households (including a spouse) are more likely to use someone else's account, and less likely to own their own.

For employment status, each respondent falls into one of four categories, represented by four variables. The variable Wage Employee captures those respondents who are employed by an employer. Self-Employed captures respondents who work for themselves (and do not report also earning a part-time wage). Unemployed equals 1 if the person does not have a job and is looking for one. Out of Workforce is a dummy that takes the value 1 when the individual does not have a job and is not looking for one. In general, we expect employed individuals to be more likely to have a bank account, since employers may require accounts to pay salaries.

Aside from controlling for individual level variables, our estimations also consider a large set of country level characteristics and policies that might be associated with the different dimensions of the use of bank accounts (captured by $x_{1 i}, x_{2 i}, x_{3 i}$, and $x_{4 i}$ in equations (1)-(4) above). The variable GDP per capita (log) is the logarithm of gross domestic product (GDP) per capita in constant 2000 U.S. dollars in 2009 and comes from the World Development Indicators of the World Bank (2012). ${ }^{8}$

We include a number of variables to proxy for the costs of opening, maintaining, and using an account. Cost of Opening a Bank Account, Cost of Maintaining a Bank Account, Cost of Direct Credit, and Cost of Debit Cards are all central banks' assessments of the costs of payment and

\footnotetext{
${ }^{8}$ Our results excluding country fixed effects are also robust to the inclusion of lagged five-year average inflation. The coefficient is insignificant in predicting account ownership or high frequency of use. The coefficient for savings is significantly negative, but does not affect the significance of our country-level variables. Results available upon request.
} 
associated services of these respective categories. These variables are dummies that take the value 1 if the country's central bank perceives the costs as medium to high, and 0 if it perceives them as negligible to low (World Bank, 2010). Although subjective, these data are consistent with actual banking costs collected for 58 countries in 2005 (Beck et al., 2008). Ex ante, we expect these variables to be negatively associated with the likelihood of using a bank account.

We also include the dummy variable Offer Basic or Low Fee Account, which takes the value 1 for countries where the government requires banks to offer a basic or low-fee account to low-income clients (CGAP, 2009). We expect this variable to be positively correlated with the use of formal accounts.

Documentation requirements are measured by information collected from regulators on "know your customer" (KYC) requirements to open accounts: (i) proof of identity through government-issued ID, (ii) proof of identity through any ID, (iii) proof of nationality or legal status in country, (iv) proof of address, (v) proof of income, and (vi) proof of employment. We construct a Principal Component of KYC Requirements. We expect more cumbersome documentation requirements to be negatively related to the use of accounts.

As the number of KYC requirements has increased in recent years, the Financial Action Task Force (FATF), recognizing that overly cautious Anti-Money Laundering and Terrorist Financing (AML/CFT) safeguards can have the unintended consequence of excluding legitimate businesses and consumers from the financial system, has emphasized the need to ensure that such safeguards also support financial inclusion (FATF, 2011). We indicate countries that have made exemptions with a dummy variable, Exception from KYC Requirements. All data come from CGAP (2009). We expect exemptions to have a positive association with account use. 
Proxies for distance barriers (or indicators of proximity to and accessibility of financial service providers) are measured by Branch Penetration and ATM Penetration, which denote the average number of commercial bank branches and automated teller machines (ATMs) per 1,000 square kilometers in 2011, respectively. These data come from the International Monetary Fund's annual Financial Access Survey (IMF, 2012). We expect higher penetration to be positively related to account use.

Proximity to bank outlets is meaningless if there is limited or no interoperability between ATMs or points of sale (POSs) across different banks (that is, if account holders of any given bank cannot use the ATMs or POSs closest to them). We include a measure of the interoperability of POSs from the World Bank Global Payment Systems Survey (World Bank, 2010). This variable measures the degree to which payment cards issued by banks in the country can be used seamlessly at any national POS terminal. This variable ranges from 1 to 3 , where lower numbers mean more interoperability; therefore, we expect a negative association between this variable and account use.

As a way to extend access to banking services to rural and other areas without a formal banking presence, some countries allow services to be offered through correspondents or agents. Correspondent Banking Permitted is a dummy variable that takes the value 1 if either private operators are allowed to provide financial services at post offices or banks are allowed to formally contract companies as banking agents, and 0 otherwise (CGAP, 2009). The dummy variable Promoting Access in Rural Areas indicates whether promoting access in rural areas is under the purview of the financial regulator (CGAP, 2010). We expect these variables to be positively related to account usage.

On top of the policy variables aimed at reducing the barriers to the use of bank accounts, we also consider the association of financial inclusion with other government initiatives intended 
to foster the use of accounts (CGAP, 2010). In particular, we include different dummy variables that take the value 1 if the government has a specific scheme to incentivize savings directly (Promoting savings, savings scheme) or to promote the use of accounts through tax incentive schemes (Promoting savings, tax incentive scheme). We also include a dummy variable for whether the government reported encouraging or mandating the payment of government transfers or social payments through bank accounts (G2P transfers: open accounts).

The extent to which individuals feel comfortable using bank accounts might also depend on whether they feel that they have sufficient information on banking products and whether they are significantly protected as consumers. To control for the extent of information disclosure on bank accounts, we include Total Disclosure Requirements for Deposits, which is the sum of demanded disclosure requirements, both at the time an account is opened and while it is maintained (CGAP, 2010). Among others, these requirements include the disclosure of the minimum balance requirement, early withdrawal penalties, and the account balance.

We also include two indices measuring the enforceability of consumer protection laws: the Monitoring Index and the Enforcement Index, which refer to the number of monitoring and enforcement actions available to the regulator, respectively (CGAP, 2010). Examples of these actions are mystery shopping and onsite inspection of financial institutions for the monitoring index, and the ability to issue public notices of violations and impose fines and penalties for the enforcement index. While we expect greater consumer protection to be correlated with greater use of bank accounts, it is hard a priori to assess the impact of information disclosure. It is possible that greater awareness and information on the costs and requirements of using bank accounts might discourage individuals from using bank accounts. 
We also speculate that the use of accounts will be affected by the extent to which individuals feel that their rights as creditors are legally protected. We include two variables to capture these effects. The Legal Rights Index variable measures the degree to which collateral and bankruptcy laws protect the rights of borrowers and lenders and thus facilitate lending (World Bank, 2011; Djankov et al., 2007). Political Risk Rating comes from the International Country Risk Guide (ICRG) of the Political Risk Services Group (2010) and assesses the political stability of a country. Among others, components of this rating are government stability, investment profile (which captures expropriation risk), and corruption. Higher ratings indicate greater political stability. We expect both the Legal Rights Index and Political Risk Rating to be positively related to the use of accounts.

In addition, we include a variable that measures the scope of explicit deposit insurance, which might be designed to build trust among consumers that their deposits are safe with the banks. The Share of Member Banks' Deposits Covered is the share of deposits of member commercial banks that are covered under the deposit insurance system (Barth et al., 2008). We expect this variable to have a positive impact on the use of bank accounts.

We also consider the association of bank ownership with the use of bank accounts. In particular, we include the Asset Share of Government-Controlled Banks and Asset Share of Foreign-Controlled Banks, which capture the percentage of assets in government-owned and foreign owned-banks, respectively. A priori, it is not clear what to expect on the correlation of these variables with the use of bank accounts. Government-owned banks are often created with the purpose of increasing the reach and depth of the financial sector, so in principle we should expect a positive association between government ownership and account use. However, some studies have failed to find a relationship between greater reach of the financial sector and government- 
owned banks (Beck, Demirguc-Kunt and Martinez Peria, 2007), and similarly, there is evidence that a greater share of government-owned banks is associated with a lower quality of financial intermediation and a misallocation of resources (Khwaja and Mian, 2005; Cole, 2009a,b). For foreign-owned banks, the existing evidence is also mixed. Some studies have found that foreign ownership is negatively related to some indicators of financial sector reach (Beck Demirguc-Kunt and Martinez Peria, 2007) and access to finance (Berger et al., 2001; Mian, 2006), while other studies find opposite results (Clarke et al., 2005, 2006).

\section{Results}

\section{Individual characteristics and the use of accounts}

Table 4 examines the link between individual characteristics and our three measures of the use of accounts: the likelihood of owning a bank account (column (1)), the probability of using the account to save (column (2)), and the likelihood of using the account frequently — that is, making three or more withdrawals a month (column (3)). In column (1) we report simple probit estimations, while in columns (2) and (3) we show results from probit estimations where we account for the selection problem resulting from the fact that the likelihood of using the account to save and the probability of using the account frequently are only observed for individuals who have an account. The table reports coefficients from the probit estimations discussed in the previous section. However, in discussing the economic significance of the results we calculate and refer to the marginal effects, which capture how the probability of account use changes with a change in the value of a regressor, holding all other variables constant. It is important to note that due to the cross-sectional nature of the data we can only interpret these results as significant correlations between individual characteristics and measures of financial inclusion and not as 
causal relationships. To isolate these correlations from the potential association between the measures of inclusion and country level characteristics, the estimations control for country fixed effects.

Column (1) shows that the likelihood of owning an account is higher among richer, older, urban, educated, employed, and married individuals. For example, the likelihood of owning an account is almost 16 percentage points lower for a person in the lowest income quintile than for someone in the highest income quintile. The likelihood of account ownership is around 12 percentage points lower for someone with up to eight years of education than for more educated counterparts, while the likelihood for a rural resident is around 3 percentage points lower than urban residents.

The results for the likelihood of using a bank account to save are very similar to those described for the probability of owning an account. The likelihood of using an account to save is around 17.5 percentage points lower for a person in the lowest income quintile than for someone in the top income quintile. For someone who is unemployed the likelihood of using an account to save is around 14 percentage points lower-and for someone who is out of the workforce, around 9 percentage points lower - than for someone who is self-employed.

The likelihood of using an account frequently is higher among older, richer, educated, or married individuals. Finally, while gender does not exhibit a statistically significant association with account ownership, females appear to use accounts less frequently.

\section{Country characteristics and the use of accounts}

The estimations in Table 5 allow us to examine how different country characteristics and policies are related to the likelihood of owning an account (column (1)), using it to save (column 
(2)), and using it frequently (column (3)), controlling for the individual level characteristics considered in Table 4. Each row in Table 5 shows the probit coefficients from different regressions controlling for individual level characteristics and for the log of GDP per capita expressed in constant 2000 U.S. dollars.

Table 5 shows that the likelihood of owning a bank account (column (1)) is lower in countries where the costs of opening and using bank accounts are higher. For example, the results suggest that the likelihood of owning an account would be, on average, 11 percentage points higher if these costs were perceived as low to negligible than if they were medium to high. On the other hand, the higher the level of branch or ATM penetration, and the higher the level of the legal rights index and of the political stability rating, the greater the likelihood of owning a bank account. Reducing distance barriers, as measured by a one-standard-deviation increase in branch or ATM penetration, would increase the likelihood of account ownership by slightly less than 6 percentage points. The likelihood of owning a bank account is also higher in countries where policy makers encourage savings through tax incentive schemes. Interestingly, greater disclosure of information on bank account products is negatively related to the likelihood of owning a bank account; if the number of disclosure requirements were to increase by three-where nine is the maximum number of requirements possible - the likelihood of owning an account would decline by around 3 percentage points.

Controlling for individual level characteristics, the likelihood of using the bank account to save is correlated with most of the same factors that are associated with the probability of owning a bank account. There are two exceptions. First, the cost of opening an account is related to the likelihood of owning a bank account, but not the probability of using it to save. This makes sense, since the results in column (2) take into account the fact that the likelihood of saving is observed 
only conditional on having an account. The cost of opening an account should be correlated with the probability of owning an account but not its uses for saving once the account is open. Second, surprisingly, the existence of tax incentive schemes to promote savings is associated with the likelihood of owning an account but uncorrelated with the probability of using the account to save.

Column (3) shows that the likelihood of using a bank account frequently is negatively related to the cost of accounts and the degree of interoperability of POSs (where higher values indicate less interoperability), but it is positively related to stronger legal rights, and greater political stability. Also, the probability of using the account three or more times a month is higher in countries where the government makes transfer payments through bank accounts, as well as in countries where savings schemes and tax incentive programs to promote savings are in place. For example, if one of these policies were in place, it would raise the likelihood of high-frequency use, on average, by 3.8 percentage points. These policies would partly cancel the negative effects of the higher costs variables (around 7.25 percentage points).

To summarize, we find that both account ownership and the use of accounts are significantly related to lower costs of accounts. Second, we find that access to financial services, as proxied by branch and ATM penetration, are significantly related to ownership of accounts and use of accounts to save. Third, better institutions, such as stronger legal rights and more political stability, are related to greater financial inclusion. Interestingly, we do not find a significant relationship in the complete sample with documentation requirements, consumer protection provisions, or policies to promote access in rural areas.

Overall, our results suggest an important relationship between financial architecture and financial inclusion. For example, in Malawi and Peru, the costs of opening an account are perceived as medium to high, and the population shares with an account are quite similar, at around 
16 and 20 percent, respectively. Our estimation results imply that if these costs were to be perceived as negligible to low, the average predicted probability of having an account at a formal financial institution would be around 6 percentage points higher in Malawi and 15 percentage points higher in Peru. ${ }^{9}$

Our model also predicts that increasing branch and ATM penetration can broaden financial inclusion. For example, Angola has approximately one bank branch per 1,000 square kilometers, while India has almost 30 . Our results suggest that the average predicted probability of having an account at a formal financial institution would be around 7 percentage points higher in both countries if the number of bank branches per 1,000 square kilometers were to increase by 36, which is roughly a one-standard-deviation increase. On the other hand, in the United States and Peru, which both have slightly more than 9 branches per 1,000 square kilometers, a one-standarddeviation increase would raise the average predicted probability of having an account at a formal financial institution by 3 percentage points in the United States but by 8 percentage points in Peru.

\section{Instrumental variables estimations}

We acknowledge that endogeneity biases could be present in the estimations discussed so far, since the distribution of financial inclusion outcomes could influence policies and many factors could jointly affect policies and financial inclusion. Hence, in discussing the results of our regressions we interpret them as associations and not as causal relationships. Moreover, given the cross-sectional nature of the data, it is very hard to come up with a good identification strategy. For example, we are not able to exploit institutional changes in some countries or other similar

\footnotetext{
${ }^{9}$ Since our model is nonlinear, this effect differs from country to country.
} 
circumstances to identify the impact of inclusion policies. As an alternative, we conduct instrumental variable estimations of the likelihood of owning an account, where we use the adoption of policies in neighboring countries as an instrument for the policies in place in a country. The assumption is that countries are likely to replicate the policies of their neighbors. Specifically, the instrumental variable $q$ for explanatory variable $x$ of country $i$ is defined as follows

$q_{i}=\sum_{j=1}^{N} \omega_{i j} x_{j}$

with $\omega_{i j}=d_{i j} / \sum_{j=1}^{N} d_{i j}$ for $i \neq j$, and $\omega_{i j}=0$ for $i=j$. The parameter $\omega_{i j}$ denotes a weight, $x_{j}$ denotes the value of explanatory variable $x$ of country $j$, and $d_{i j}$ is a measure of similarity of countries $i$ and $j$. The weights are normalized so that they lie in the closed interval $[0,1]$ and sum to unity. The measure of similarity $d_{i j}$ is based on how close countries are to each other. This captures the idea that countries that are close to each other are more likely to have similar policies in place and share a similar set of institutions. The farther away countries are from each other, the less likely they look to each other for adopting policies. Two approaches are being taken to determine $d_{\mathrm{ij}}$. The first is based on whether countries are in the same region based on the regional classification of the World Bank. These regions are East Asia and the Pacific, Europe and Central Asia, Latin America and the Caribbean, Middle East and North Africa, South Asia, and SubSaharan Africa. High income countries are considered to be a separate region. When country $i$ and country $j$ are in the same region, $d_{i j}$ is 1 , otherwise it is 0 . The second approach is based on the geographical distance between countries. For countries $i$ and $j, d_{i j}$ equals the inverse of the distance in kilometers between the most populous cities of countries $i$ and $j$, respectively. Hence, the smaller the distance between two countries, the higher the weight. 
Table 6 presents the results from the instrumental variable estimations for the likelihood of owning an account. We restrict our estimations to this measure of use because it is very complicated to conduct IV estimations in the context of the probit selection models that we estimate for the likelihood of using an account to save and for the frequency of account use. Column (1) repeats the estimation results that are given in column (1) of Table 5. A linear probability model instead of a probit model is also used to facilitate the analysis of the instrumental variables estimations, which also follow a linear probability model. The estimation results of the linear probability model are shown in column (2). Columns (3), (4), and (5) present the two-stage least squares (2SLS) estimations where instruments are based on the regional average of each variable for each country. Column (3) shows the second stage estimation results, column (4) presents the coefficients for the first stage estimations, and column (5) provides the corresponding F-statistic to assess whether the instruments used in the first stage are weak. Columns (6), (7), and (8) report the 2SLS estimations, where instruments are based on distance to other countries. Column (6) presents the second stage estimation results, column (7) shows the coefficient of the instrumental variable of the first stage estimation, and column (8) provides the corresponding $F$ statistics to assess instrumental variable strength.

Overall, the 2SLS results in Table 6 for the likelihood of owning a bank account are largely consistent with the original probit estimations. We find that the likelihood of owning a bank account is negatively related to the costs associated with accounts and positively related to the presence of bank outlets (ATM and Branches) and to the existence of strong legal institutions and a stable political environment.

\section{Interaction effects}


In Table 5 we assumed that all country characteristics and policies relate to all individuals equally. In contrast, in Tables 7, 8, and 9 we relax this assumption and examine how country characteristics and policies relate to individuals who are more likely to be excluded or that tend to be the specific target of government policies to promote inclusion. In particular, we include interactions between the country level variables and some individual level characteristics; namely: location, income, gender and age.

Table 7 examines how specific policies and country characteristics relate to the likelihood of owning a bank account for rural residents (column (1)), individuals in the poorest $20 \%$ (column (2)), females (column (3)), and young individuals (column (4)). Results in column (1) show that policies such as offering basic or low-fee accounts, granting exemptions from KYC requirements, and encouraging the use of bank accounts for government payments increase the likelihood of owning a bank account among rural residents, relative to urban residents. For example, the additional likelihood of account ownership for rural residents is around 4, 2.5, and 2.5 percentage points higher for these variables, respectively. In addition, the probability of owning a bank account increases significantly among rural residents (relative to urban residents) with lower costs of accounts, greater branch penetration, and strong consumer protection and political stability. The results in Table 7 column (2) indicate that the geographic presence of bank branches has a relatively higher correlation with the likelihood of account ownership among the (relative) poor. For example, the likelihood of account ownership would increase by almost an additional percentage point among the poor if branch penetration were to increase by one standard deviation. Similarly, deposit insurance coverage and political stability are positive and significant for the lowest income quintile. 
As shown in Table 7 column (3), among females higher costs of having a debit card have a stronger impact on their use of accounts relative to males. Similarly, political stability and savings schemes also have a stronger, in this case positive, correlation with the likelihood of owning an account for female users. According to the results in Table 7, column (4) young individuals are more sensitive, relative to older persons, when it comes to increases in the cost of using accounts, but less sensitive when it comes to physical access to banking outlets (this might be because they are more comfortable with using mobile or internet banking). At the same time, young people appear to be more sensitive to the presence of government-owned banks in the country.

Table 8 shows the results of the interactions of country characteristics and policy variables with individual level variables for the estimations for the likelihood of using an account to save. The results in Table 8 column (1) indicate that the likelihood of using the account to save increases among rural residents with lower costs of bank accounts, fewer KYC requirements, the practice of agent or correspondent banking, and strong consumer protection policies. Making correspondent banking available would increase the likelihood of using an account to save by at least another 2 percentage points for rural residents.

Column (2) in Table 8 presents results for the probability of using a bank account to save where we interact the country characteristics and policy variables with a dummy for the poorest individuals (lowest $20 \%$ of income). We find that the practice of correspondent banking, the presence of government banks, and policies to promote savings through saving schemes are significantly related to a higher likelihood of using an account to save for adults in the bottom income quintile. The effect of correspondent banking is especially large: for this group, the 
likelihood of using an account to save would increase by roughly an additional 5 percentage points if correspondent banking were allowed.

The estimates in Table 8, column (3) indicate that in terms of the likelihood of using an account to save women are less sensitive to the presence of branches and to the monitoring aspects of consumer protection. In contrast, women appear to be more sensitive to the presence of deposit insurance. Column (4) of Table 8 shows the results for the interaction of country characteristics and policy variables with a dummy for individuals young individuals - those between 15 and 24 . We find that when it comes to the use of bank accounts to save, the youth are more responsive to the presence of bank branches, to whether correspondents are allowed and to the whether political risks are low in the country. On the other hand, relative to older individuals, younger ones are surprisingly less responsive to KYC documentation requirements.

Table 9 shows the results for the interactions of country characteristics and policy variables with individual level variables for the estimations for the frequency of account use. Column (1) in Table 9 shows that the probability that rural residents use bank accounts relatively more frequently is higher in countries with greater penetration by financial services providers, strong consumer protection enforcement, and more stable political institutions. Surprisingly, in countries that have policies to promote access in rural areas, rural individuals are less likely to use accounts frequently, which may reflect reverse causality - that is, governments are more likely to have taken recent steps to expand financial inclusion in rural areas in countries with greater financial inequality.

In Table 9, column (2) we interact the lowest income quintile dummy (indicating the poorest 20 percent of earners within the country) with different country level characteristics and policy variables to examine the relative importance of these variables for the poor. We find that apart from the exemption from KYC requirements (that has the wrong predicted value), hardly any 
variable enters significantly. One possible explanation for this finding is that there is not enough variation in the frequency of use of accounts among adults in the poorest income quintile.

Column (3) in Table 9 shows the interactions of the country characteristics and the policy variables with a dummy which is equal to one for females. The estimates indicate that the physical presence of bank branches and ATMs is less likely to influence the frequent use of accounts by females relative to males. Finally, column (4) shows interactions with a dummy for young individuals (those between 15 and 24). The results suggest that policies like basic accounts, reduced documentation requirements, greater disclosure requirements of deposit fees, and G2P transfers via bank accounts are less likely to influence the frequency with which young people use bank accounts. Also, similar to the findings for the other account use measures, the frequency of use among young individuals is less likely to be driven by the presence of brick and mortar branches.

Overall, the interaction results discussed in this section indicate that the extent to which country characteristics and policies designed to improve financial inclusion are correlated with different measures of financial inclusion varies depending on the features of the individuals, with women and younger users being somewhat harder to entice.

\section{Barriers to financial inclusion}

Table 10 estimates how different individual characteristics affect the likelihood of reporting one of the reasons for not having an account (cost, distance, and the like). Table 11 uses the same sample of unbanked adults to test whether country characteristics — such as on the cost of banking and bank penetration — and different policy measures are associated with the likelihood of reporting a specific barrier to having an account (conditional on not having an account). 
Table 10 shows that those who are poor, less educated, unemployed, or rural residents are more likely to report costs as a barrier to account ownership. Lack of necessary documentation is also significantly more likely to be cited as a barrier by less educated or rural residents, as well as by younger or single adults, who may lack residency documents because of relocation for work or other reasons. Distance is significantly more likely to be cited as a barrier by rural residents, as well as by less educated, married, or poor adults, who may find it more costly and difficult to travel long distances to access financial services. Male and wealthier adults are more likely to report that they don't have an account because they don't trust banks. Poor or unemployed adults are more likely to say that they don't have enough money to use an account. Finally, those who are poor, older, urban, or unemployed are more likely to cite not having enough money as the only reason for not having an account.

Table 11 shows how different country characteristics and policies affect the likelihood of reporting various barriers to account ownership. Each row in table 11 shows results from different regressions controlling for individual level characteristics and for the log of 2009 GDP per capita expressed in constant 2000 U.S. dollars. First, the cost of banking is more likely to be reported as a barrier in countries with greater costs of maintaining an account. The cost of banking is also less likely to be reported as a barrier in countries with a greater share of government-controlled banks, which may be perceived to offer wider rural penetration and simpler, less expensive account options. However, as discussed earlier, we find no evidence that government-owned banks are actually associated with greater account ownership or use.

Documentation is more likely to be reported as a barrier in countries with a smaller share of government-owned banks and a greater share of foreign-owned banks. This suggests that financially excluded individuals may perceive foreign (government) banks as more (less) likely to have more stringent documentation requirements. Distance is more likely to be reported as a barrier 
in countries with lower branch penetration. Also, in countries with a smaller share of governmentowned banks and a higher share of foreign-owned banks, financially excluded individuals are more likely to perceive distance as a barrier to account use.

Trust is more likely to be reported as a barrier in countries with lower branch penetration and a larger share of foreign-controlled banks. This significant association may suggest a relationship between familiarity with banks and greater trust and, by extension, the importance of financial education in locations with less bank penetration.

Finally, financially excluded individuals are more likely to report that they perceive not having enough money as a barrier to having an account in countries with higher banking costs. It might be the case that these respondents don't have enough money to use what banking services are currently offered —or what the respondents perceive to be available. Use of bank accounts for government payments and tax incentive schemes to promote savings are also associated with a lower likelihood to report "not enough money" as a barrier by the unbanked. If we focus only on financially excluded individuals who report not having enough money as their only barrier, we observe that the presence of basic or low-fee accounts, correspondent banking, consumer protection, and accounts to receive G2P payments lower the likelihood that these individuals will cite lack of funds as a barrier. This suggests that government policies to promote inclusion may be related to a higher likelihood that individuals perceive that financial services are within their reach.

\section{Conclusion}

Financial inclusion can bring many welfare benefits to individuals. Yet we know very little about the factors underpinning financial inclusion across individuals and countries. Using data for 123 countries and over 124,000 individuals, this paper tries to understand what factors are correlated with the use of formal accounts and what policies are especially effective among those 
most likely to be excluded. We find that greater financial inclusion is associated with a better enabling environment to access financial services, such as lower banking costs and greater proximity to branches. . Stronger legal rights and political stability also matter for inclusion. The effectiveness of policies to promote inclusion varies depending on the characteristics of the individuals considered. In general, policies appear to be relatively less effective in encouraging account use by women and youth.

We also study the factors associated with perceived barriers to account use among those who are financially excluded. Those who are financially excluded report lower barriers to account use in countries with lower costs of accounts and greater penetration of financial service providers. We also find that among those who report lack of money as the main barrier to account use, government policies to promote inclusion can increase the likelihood that individuals perceive that financial services are within their reach. Overall, our results suggest a role for policy to expand the pool of eligible account users and increase account use to save and with higher frequency. 


\section{References}

Aghion, P., and P. Bolton. 1997. "A Theory of Trickle-Down Growth and Development." Review of Economics Studies 64: 151-72.

Aportela, F. 1999. "Effects of Financial Access on Savings by Low-Income People." MIT Department of Economics Dissertation Chapter 1.

Ashraf, N., D. Karlan, and W. Yin. 2006. "Tying Odysseus to the Mast: Evidence from a Commitment Savings Product in the Philippines." Quarterly Journal of Economics 121(2), 673-697.

Ashraf, N., D. Karlan, and W. Yin. 2010. "Female Empowerment: Further Evidence from a Commitment Savings Product in the Philippines." World Development 28 (3): 333-44.

Barr, M. 2004. "Banking the Poor”. Yale Journal of Regulation, 21(1), 121-237.

Barth, J.R., G. Caprio Jr., and R. Levine. 2008. "Bank Regulations Are Changing: For Better or Worse?" Mimeo. Washington, DC: World Bank.

Beck, T., A. Demirgüç-Kunt, and M. S. Martinez Peria. 2007. "Reaching Out: Access to and Use of Banking Services across Countries." Journal of Financial Economics 85: 234-66.

Beck, T., A. Demirgüç-Kunt, and M. S. Martinez Peria. 2008. "Banking Services for Everyone? Barriers to Bank Access and Use Around the World." World Bank Economic Review 22 (3): 397-430.

Beck, T., A. Demirguc-Kunt, and O. Merrouche. 2012. "Islamic vs. Conventional Banking: Business Model, Efficiency, and Stability." Journal of Banking and Finance, forthcoming.

Berger, A. N., L. F. Klapper, and G. F. Udell. 2001. "The Ability of Banks to Lend to Informationally Opaque Small Businesses." Journal of Banking and Finance 25 (12): 2127-67.

Bjornskov, C. 2007. "The Determinants of Trust." Public Choice 130 (21): 1-21.

Cihak, M., A. Demirgüç-Kunt, M.S. Martínez Pería, and A. Mohseni-Cheraghlou. 2012. "Bank Regulation and Supervision around the World: A Crisis Update." World Bank Policy Research Working Paper.

CGAP (Consultative Group to Assist the Poor). 2009. Financial Access 2009: Measuring Access to Financial Services around the World. Washington, DC: CGAP.

CGAP (Consultative Group to Assist the Poor), 2010. Financial Access 2010: The State of Financial Inclusion Through the Crisis. Washington, DC: CGAP. 
Clarke, G., R. Cull, and M. S. Martínez Pería. 2006, "Foreign Bank Participation and Access to Credit Across Firms in Developing Countries." Journal of Comparative Economics 34 (4): 774-95.

Clarke, G., R. Cull, M. S. Martínez Pería, and S. M. Sánchez. 2005. "Bank Lending to Small Businesses in Latin America: Does Bank Origin Matter?" Journal of Money, Credit and Banking 37 (1): 83-118.

Clausen, B., A. Kraay, and Z. Nyiri. 2011. "Corruption and Confidence in Public Institutions: Evidence from a Global Survey.” World Bank Economic Review 25: 212-249.

Cole, S. A. 2009a. "Financial Development, Bank Ownership, and Growth: or, Does Quantity Imply Quality?" Review of Economics and Statistics 91 (1): 33-51.

Cole, S. A. 2009b. "Fixing Market Failures or Fixing Elections? Elections, Banks, and Agricultural Lending in India." American Economic Journal Applied Economics 1 (1): 219-50.

Collins, D., J. Morduch, S. Rutherford, and O. Ruthven. 2009. Portfolios of the Poor: How the World's Poor Live on \$2 a Day. Princeton: Princeton University Press.

Deaton, A. 2008. "Income, Health, and Well-Being around the World: Evidence from the Gallup World Poll." Journal of Economic Perspectives 22: 53-72.

Deaton, A. 2009. "Instruments of Development: Randomization in the Tropics, and the Search for the Elusive Keys to Economic Development," NBER Working Paper 14690.

Demirgüç-Kunt, A., T. Beck, and P. Honohan. 2008. Finance for All? Policies and Pitfalls in Expanding Access. Washington, DC: World Bank.

Demirguc-Kunt, A., and L. Klapper. 2013. "Measuring Financial Inclusion: The Global Findex Database." Brookings Papers on Economic Activity, Spring 2013, 279-321.

Djankov, S., C. McLiesh, and A. Shleifer. 2007. "Private Credit in 129 Countries." Journal of Financial Economics 84: 299-329.

Dupas, P., and J. Robinson. 2009. "Savings Constraints and Microenterprise Development: Evidence from a Field Experiment in Kenya." National Bureau of Economic Research Working Paper 14693.

Financial Action Task Force (FATF). 2011. Anti-money Laundering and Terrorist Financing Measures and Financial Inclusion. FATF/OECD, Paris.

Gallup, 2012. Gallup World Poll. Washington, DC: Gallup.

Gross, M., J. Hogarth, and M. Schmeiser. 2012. "Use of Financial Services by the Unbanked and Underbanked and the Potential for Mobile Financial Services Adoption." Federal Reserve Bulletin 98, 4. 
Guiso, L., P. Sapienza, and L. Zingales. 2004. "The Role of Social Capital in Financial Development." American Economic Review 94 (3): 526-56.

Hogarth, J. M., C.E., Anguelov and J. Lee. 2004. "Why Don't Households Have a Checking Account?" Journal of Consumer Affairs 38, 1-34.

Hogarth, J. M., C.E., Anguelov and J. Lee. 2005. "Who Has a Bank Account? Exploring Changes Over Time. 1989-2001.” The Journal of Family and Economic Issues 26, 7-30.

Honohan, P. 2008. "Cross-Country Variation in Household Access to Financial Services.” Journal of Banking and Finance 32: 2493-500.

International Monetary Fund (IMF). 2012. "Financial Access Survey." Washington, DC: International Monetary Fund.

Karlan, D. and J. Morduch. 2009. “Access to Finance.” In D. Rodrik and M, Rosenzweig, eds. Handbook of Development Economics, Volume 5. Amsterdam: Elsevier. 4704-4784.

Karlan, D., M. McConnell, S. Mullainathan, and J. Zinman. 2010. Getting to the Top of Mind: How Reminders Increase Saving. NBER Working Paper 16205.

Kast, F., S. Meier, and D. Pomeranz. 2012. "Under-Savers Anonymous: Evidence on Self-Help Groups and Peer Pressure as a Savings Commitment Device." NBER Working Paper No. 18417.

Kendall, J., N. Mylenko, and A. Ponce. 2010. "Measuring Financial Access around the World." World Bank Policy Research Working Paper 5253.

Khwaja, A., and A. Mian. 2005. "Do Lenders Favor Politically Connected Firms? Rent Provision in an Emerging Financial Market.” Quarterly Journal of Economics 120 (4): 1371-411.

Lemke, D. and W. Reed 2001. "War and Rivalry among Great Powers." American Journal of Political Science 45, 457-469.

Lusardi, A. 2010. "Americans' Financial Capability." Report Prepared for the United States Government Financial Crisis Inquiry Committee (FCIC).

Marinescu, I., 2007. "Are Judges Sensitive to Economic Conditions? Evidence from UK Employment Tribunals” University of Chicago Harris School Working paper 08.02.

Mian, A.R. 2006. "Distance Constraints: The Limits of Foreign Lending in Poor Economies." Journal of Finance 61: 1465-1505

Rhine, S. and W. Greene. 2006. "The Determinants of Being Unbanked for US Immigrants." Journal of Consumer Affairs 40, 21-40. 
Rhine, S., W. Greene, and M. Toussaint-Comeau. 2006. "The Importance of Check-Cashing Businesses to the Unbanked: Racial/Ethnic Differences." Review of Economics and Statistics 88 (1), 146-157.

Rodrik, D. 2008. “The New Development Economics: We Shall Experiment, But How Shall We Learn?” Harvard Kennedy School Faculty Research Working Paper Series 08055.

Sacks, D.W., B. Stevenson, and J. Wolfers. 2010. "Subjective Well-Being, Income, Economic Development and Growth.” NBER Working Papers 16441, National Bureau of Economic Research, Inc.

Sapienza, P., and L. Zingales. 2011. “A Trust Crisis.” University of Chicago Working Paper.

Sartori, A., 2003. "An Estimator for Some Binary-Outcome Selection Models Without Exclusion Restrictions," Political Analysis 11, 111-138.

Schaner, S. 2013. "The Persistent Power of Behavioral Change: Evidence from Long-Run Savings Subsidies for the Poor". Mimeo. Dartmouth College. http://www.dartmouth.edu/ sschaner/main_files/Schaner_LongRun.pdf

Stevenson, B. and J. Wolfers. 2008. "Economic Growth and Subjective Well-Being: Reassessing the Easterlin Paradox.” Brooking Papers on Economic Activity 39: 1-102

Stevenson, B. and J. Wolfers, 2011. "Trust in Public Institutions over the Business Cycle." American Economic Review 101: 281-287World Bank. 2010. Payment Systems Worldwide: A Snapshot. Outcomes of the Global Payment Systems Survey 2010. Washington, DC: World Bank.

World Bank. 2011. Doing Business: Measuring Business Regulation. Washington, DC: World Bank.

World Bank. 2012. World Development Indicators. Washington, DC: World Bank. 
Table 1: List of countries

\begin{tabular}{|c|c|c|c|c|}
\hline Afghanistan & Comoros & Indonesia & Mongolia & Sri Lanka \\
\hline Angola & Congo, Dem. Rep. & Iraq & Mozambique & Swaziland \\
\hline Argentina & Congo, Rep. & Ireland & Nepal & Sweden \\
\hline Armenia & Costa Rica & Israel & Netherlands & Syrian Arab Republic \\
\hline Australia & Cyprus & Italy & New Zealand & Taiwan \\
\hline Austria & Czech Republic & Jamaica & Nicaragua & Tajikistan \\
\hline Azerbaijan & Denmark & Japan & Niger & Tanzania \\
\hline Bangladesh & Djibouti & Kazakhstan & Nigeria & Thailand \\
\hline Belarus & Dominican Republic & Korea, Rep. & Pakistan & Togo \\
\hline Belgium & Ecuador & Kyrgyz Republic & Panama & Trinidad and Tobago \\
\hline Benin & Egypt, Arab Rep. & Lao PDR & Paraguay & Tunisia \\
\hline Bolivia & El Salvador & Latvia & Peru & Turkey \\
\hline Botswana & Estonia & Lebanon & Philippines & Turkmenistan \\
\hline Brazil & Finland & Lesotho & Poland & Uganda \\
\hline Bulgaria & France & Liberia & Portugal & Ukraine \\
\hline Burkina Faso & Gabon & Lithuania & Romania & United States \\
\hline Burundi & Georgia & Luxembourg & Russian Federation & Uruguay \\
\hline Cambodia & Ghana & Malawi & Senegal & Uzbekistan \\
\hline Cameroon & Greece & Malaysia & Sierra Leone & Venezuela, RB \\
\hline Canada & Guinea & Mali & Singapore & Vietnam \\
\hline Central African Republic & Haiti & Malta & Slovak Republic & West Bank and Gaza \\
\hline Chad & Honduras & Mauritania & Slovenia & Yemen, Rep. \\
\hline Chile & Hong Kong SAR, China & Mauritius & Somalia & Zambia \\
\hline China & Hungary & Mexico & South Africa & \\
\hline Colombia & India & Moldova & Spain & \\
\hline
\end{tabular}




\section{Table 2: Data description and sources Panel A: Individual level variables}

\begin{tabular}{l}
\hline Variable \\
\hline Account \\
Savings (conditional on formal \\
account)
\end{tabular}
account)

Frequency of use (conditional on formal account

Too expensive

Lack of necessary documentation

Too far away

No trust

Not enough money

Not enough money, only reason

Female

Age

Age squared

Rural

Income: poorest $20 \%$

Income: second $20 \%$

Income: middle $20 \%$

Income: fourth $20 \%$

Income: richest $20 \%$

$0-8$ years of education
Description

Dummy equal 1 if respondent reported to currently have, possibly together with someone else,

a bank account at a formal financial institution---a bank, credit union, cooperative, post office, or microfinance institution. This includes having a debit card.

Dummy equal to 1 if respondent reported to have saved or set aside money in the past 12 months using an account at a bank, credit union, cooperative, or microfinance institution.

Dummy equal to 1 if respondent reported to have taken money out of their personal account(s) 3 or more times in a typical month. This includes cash withdrawals, electronic payments or purchases, checks, or any other time money is removed from their account(s) by themselves or others.

Dummy equal to 1 if respondent answered affirmative to "They are too expensive" as a reason why he or she does not have an account at a bank, credit union, or other financial institution. Asked only to those without an account.

Dummy equal to 1 if respondent answered affirmative to "You don't have the necessary documentation (ID, wage slip)" as a reason why he or she does not have an account at a bank, credit union, or other financial institution. Asked only to those without an account.

Dummy equal to 1 if respondent answered affirmative to "They are too far away" as a reason why he or she does not have an account at a bank, credit union, or other financial institution. Asked only to those without an account.

Dummy equal to 1 if respondent answered affirmative to "You don't trust them" as a reason why he or she does not have an account at a bank, credit union, or other financial institution. Asked only to those without an account.

Dummy equal to 1 if respondent answered affirmative to "You don't have enough money to use them" as a reason why he or she does not have an account at a bank, credit union, or other financial institution. Asked only to those without an account.

Dummy equal to 1 if respondent answered affirmative to "You don't have enough money to use them" as the only reason why he or she does not have an account at a bank, credit union, or other financial institution. Asked only to those without an account.

Dummy that takes the value 1 if the respondent is female and 0 otherwise.

Gallup

Age in years

Gallup

Age in years, squared

Gallup

Dummy that takes the value 1 if the respondent lives in a rural area and 0 otherwise. A rural area is defined as a town or rural village with less than 50,000 inhabitants. If this information is unavailable, a rural area is based on the interviewer's perception of whether a respondent lives in a rural area, on a farm, in a small town, or in a village.

Dummy that takes the value 1 if the respondent falls in the lowest income quintile and 0 otherwise. Income quintiles are based on the incomes of the respondents in a country.

Dummy that takes the value 1 if the respondent falls in the second lowest income quintile and 0 otherwise. Income quintiles are based on the incomes of the respondents in a country.

Dummy that takes the value 1 if the respondent falls in the middle income quintile and 0 Gallup otherwise. Income quintiles are based on the incomes of the respondents in a country.

Dummy that takes the value 1 if the respondent falls in the second highest income quintile and Gallup 0 otherwise. Income quintiles are based on the incomes of the respondents in a country.

Dummy that takes the value 1 if the respondent falls in the highest income quintile and 0 Gallup otherwise. Income quintiles are based on the incomes of the respondents in a country.

Dummy that takes the value 1 if the respondent completed elementary education or less (up to 8 Gallup years of education) and 0 otherwise. 


\begin{tabular}{|c|c|c|}
\hline (9-15 years of education & $\begin{array}{l}\text { Dummy that takes the value } 1 \text { if the respondent completed secondary education and some } \\
\text { education beyond secondary education }(9-15 \text { years of education) and } 0 \text { otherwise. }\end{array}$ & Gallup \\
\hline$>15$ years of education & $\begin{array}{l}\text { Dummy that takes the value } 1 \text { if the respondent completed four years of education beyond high } \\
\text { school and/or received a } 4 \text {-year college degree and } 0 \text { otherwise. }\end{array}$ & Gallup \\
\hline Employed for employer & $\begin{array}{l}\text { Dummy that takes the value } 1 \text { if the respondent is employed for an employer, either full or part } \\
\text { time, and } 0 \text { otherwise. }\end{array}$ & Gallup \\
\hline Unemployed & Dummy that takes the value 1 if the respondent is unemployed and 0 otherwise. & Gallup \\
\hline Out of workforce & Dummy that takes the value 1 if the respondent is out of the workforce and 0 otherwise. & Gallup \\
\hline Self-employed & Dummy that takes the value 1 if the respondent is self-employed and 0 otherwise. & Gallup \\
\hline Married & Dummy that takes the value 1 if the respondent is married and 0 otherwise. & Gallup \\
\hline Divorced/Separated $(0 / 1)$ & Dummy that takes the value 1 if the respondent is divorced or separated and 0 otherwise. & Gallup \\
\hline Log of household size & Logarithm of household size. & Gallup \\
\hline
\end{tabular}

\section{Panel B: Country level variables}

Variable
Log of GDP per capita
Costs of opening a bank acco
Costs of maintaining a bank
account

Costs of direct credit

Costs of debit cards

Offer basic or low fee account

Principle component of KYC requirements

Exception from KYC requirements

Branch penetration (geographic)

ATM penetration (geographic)

Interoperability POSs

Correspondent banking permitted
Description

Logarithm of GDP per capita in constant 2000 US \$ of 2009. Winsorized.

Central Bank's assessment of the costs of payment and associated services of opening a bank account. Dummy that takes the value 1 if the costs are perceived as medium to high and 0 if they are perceived as negligible to low. Winsorized.

Central Bank's assessment of the costs of payment and associated services of maintaining a bank account. Dummy that takes the value 1 if the costs are perceived as medium to high and 0 if they are perceived as negligible to low. Winsorized.

Central Bank's assessment of the costs of payment and associated services of direct credit. Dummy that takes the value 1 if the costs are perceived as medium to high and 0 if the costs are perceived as negligible to low. Winsorized.

Central Bank's assessment of the costs of payment and associated services of debit cards. Dummy that takes the value 1 if the costs are perceived as medium to high and 0 if the costs are perceived as negligible to low. Winsorized.

Dummy equal to 1 if country requires banks to offer a basic or low fee account to low income clients. Winsorized.

Principle component of information requested as part of "know your customer" regulation. These include: i) proof of identity through government issued ID, ii) proof of identity through any ID, iii) proof of nationality/legal status in country, iv) proof of address, v) proof of income, and vi) proof of employment.

Dummy equal to 1 if country has an exception from "know your customer" requirements for low-income applicants or small accounts. Winsorized.

Amount of commercial bank branches per 1,000 square kilometers in 2011. Winsorized.

Amount of automated teller machines (ATMs) per 1,000 square kilometers in 2011. Winsorized.

Interoperability of points of sales (POSs) terminals, where full interoperability means that all payment cards issued by banks in the country can be used seamlessly in any POS terminal in the country. 1 is the highest and 3 the lowest value. Winsorized.

Dummy that takes the value 1 if private operators are allowed to provide financial services at post offices or banks are allowed to formally contract companies as banking agents and 0 otherwise. Winsorized.
CGAP

FAS (2012) 
Promoting access in rural areas

Share of member banks' deposits covered

Total disclosure requirements for deposits

Consumer protection: Monitoring index

Consumer protection:

Enforcement index

Asset share of government controlled banks

Asset share of foreign controlled banks

Legal rights index

Political risk rating

G2P transfers: open accounts

Promoting savings, Savings scheme

Promoted savings, Tax incentive scheme
Dummy that takes the value 1 if promoting access in rural areas is under the purview of the financial regulator and 0 otherwise. Winsorized.

Share of the deposits of member commercial banks that are covered by the deposit insurance scheme. Most recent data over the period 2008-2010 are used. Winsorized.

Total disclosure requirements for deposits, both upon opening and periodic. These requirements include: i) annual percentage yield and interest rate, ii) method of compounding, iii) minimum balance requirement, iv) fees and penalties, v) early withdrawal penalties, vi) annual percentage yield calculation, vii) amount of interest earned, viii) fees imposed, and ix) account balance. Winsorized.

Number of monitoring actions available to the regulator. These actions include: i) mystery shopping, ii) consumer interviews, iii) receive complaints statistics, iv) operate complaints hotline, v) monitor ads and websites, and vi) onsite inspection of financial institutions. Winsorized.

Number of enforcement actions available to the regulator. These actions include: i) require refund of excess charges, ii) issue public notice of violations, iii) withdraw license to operate, iv) withdraw misleading ads, v) impose fines and penalties, and vi) issue warnings to financial institutions. Winsorized.

Share of banking system's assets that was in banks that were government controlled. Most recent data over the period 2008-2010 are used. Winsorized.

Share of banking system's assets that was in banks that were foreign controlled. Most recent data over the period 2008-2010 are used. Winsorized.

Strength of legal rights index measures the degree to which collateral (8) and bankruptcy (2) laws protect the rights of borrowers and lenders and thus facilitate lending. Winsorized.

The political risk rating assesses the political stability of a country. Among others, components of the index are government stability, investment profile, and corruption. Winsorized.

Dummy that takes the value 1 if a country reported encouraging or mandating conducting government transfers through the banking system and 0 otherwise. Winsorized.

Dummy that takes the value 1 if the country has a matched savings scheme in place to CGAP promote savings and 0 otherwise. Winsorized.

Dummy that takes the value 1 if the country provides tax incentives to promote savings and 0 otherwise. Winsorized.

CGAP

(2009)

CGAP

CGAP

CGAP

DB

ICRG

BRS (2012)

BRS (2012)

The 3 largest and smallest values of a variable are replaced by the $4^{\text {th }}$ largest and smallest, respectively, when the variable is winsorized. 
Table 3: Summary statistics

\section{Panel A: Individual level variables}

\begin{tabular}{|c|c|c|c|c|c|}
\hline Variable & Obs. & Mean & Std. Dev. & Min & Max \\
\hline Formal account & 125073 & 0.446 & 0.497 & 0 & 1 \\
\hline Savings, conditional on formal account & 59923 & 0.412 & 0.492 & 0 & 1 \\
\hline Frequency of use, conditional on formal account & 59923 & 0.511 & 0.500 & 0 & 1 \\
\hline Too expensive & 65280 & 0.266 & 0.442 & 0 & 1 \\
\hline Documentation requirements & 65228 & 0.215 & 0.411 & 0 & 1 \\
\hline Too far away & 65226 & 0.215 & 0.411 & 0 & 1 \\
\hline No trust & 65271 & 0.178 & 0.383 & 0 & 1 \\
\hline Not enough money & 65403 & 0.698 & 0.459 & 0 & 1 \\
\hline Not enough money (only reason) & 65240 & 0.303 & 0.460 & 0 & 1 \\
\hline Female & 125073 & 0.517 & 0.500 & 0 & 1 \\
\hline Age & 125073 & 38.707 & 17.254 & 13 & 99 \\
\hline Age squared & 125073 & 1795.897 & 1549.184 & 169 & 9801 \\
\hline Rural & 125073 & 0.594 & 0.491 & 0 & 1 \\
\hline Income: poorest $20 \%$ & 125073 & 0.216 & 0.411 & 0 & 1 \\
\hline Income: second $20 \%$ & 125073 & 0.207 & 0.405 & 0 & 1 \\
\hline Income: middle $20 \%$ & 125073 & 0.201 & 0.401 & 0 & 1 \\
\hline Income: fourth $20 \%$ & 125073 & 0.195 & 0.396 & 0 & 1 \\
\hline Income: richest $20 \%$ & 125073 & 0.182 & 0.386 & 0 & 1 \\
\hline $0-8$ years of education & 125073 & 0.432 & 0.495 & 0 & 1 \\
\hline $9-15$ years of education & 125073 & 0.471 & 0.499 & 0 & 1 \\
\hline$>15$ years of education & 125073 & 0.096 & 0.295 & 0 & 1 \\
\hline Employed for employer & 125073 & 0.305 & 0.461 & 0 & 1 \\
\hline Unemployed & 125073 & 0.079 & 0.269 & 0 & 1 \\
\hline Out of workforce & 125073 & 0.392 & 0.488 & 0 & 1 \\
\hline Self-employed & 125073 & 0.224 & 0.417 & 0 & 1 \\
\hline Married & 125073 & 0.518 & 0.500 & 0 & 1 \\
\hline Divorced/Separated & 125073 & 0.044 & 0.206 & 0 & 1 \\
\hline Log of household size & 125073 & 1.460 & 0.612 & 0 & 4.625 \\
\hline Formal account & 125073 & 0.446 & 0.497 & 0 & 1 \\
\hline
\end{tabular}

Panel B: Aggregate-level variables

\begin{tabular}{|c|c|c|c|c|c|}
\hline Variable & Obs. & Mean & Std. Dev. & Min & Max \\
\hline Log of GDP per capita & 120 & 7.769 & 1.563 & 5.189 & 10.420 \\
\hline Costs of opening a bank account & 78 & 0.179 & 0.386 & 0 & 1 \\
\hline Costs of maintaining a bank account & 78 & 0.346 & 0.479 & 0 & 1 \\
\hline Costs of direct credit & 72 & 0.417 & 0.496 & 0 & 1 \\
\hline Costs of debit cards & 75 & 0.200 & 0.403 & 0 & 1 \\
\hline Offer basic or low fee account & 103 & 0.136 & 0.344 & 0 & 1 \\
\hline Principle component of KYC requirements & 103 & 0.000 & 1.678 & -2.309 & 2.961 \\
\hline Exception from $\mathrm{KYC}$ requirements & 103 & 0.165 & 0.373 & 0 & 1 \\
\hline Branch penetration (geographic) & 111 & 22.557 & 36.566 & 0.103 & 142.857 \\
\hline ATM penetration (geographic) & 107 & 64.560 & 129.263 & 0.149 & 612.500 \\
\hline Interoperability POSs & 87 & 1.667 & 0.787 & 1 & 3 \\
\hline Correspondent banking permitted & 103 & 0.534 & 0.501 & 0 & 1 \\
\hline Promoting access in rural areas & 103 & 0.398 & 0.492 & 0 & 1 \\
\hline Share of member banks' deposits covered & 52 & 43.704 & 26.635 & 2 & 83 \\
\hline Total disclosure requirements for deposits & 103 & 4.437 & 3.105 & 0 & 9 \\
\hline Consumer protection: Monitoring index & 103 & 2.049 & 1.580 & 0 & 5 \\
\hline Consumer protection: Enforcement index & 103 & 2.864 & 2.160 & 0 & 6 \\
\hline Asset share of government controlled banks & 92 & 16.800 & 19.193 & 0 & 71 \\
\hline Asset share of foreign controlled banks & 88 & 45.574 & 29.866 & 5.580 & 94.560 \\
\hline Legal rights index & 120 & 5.358 & 2.449 & 1 & 10 \\
\hline Political risk rating & 103 & 66.999 & 12.051 & 42.375 & 88.583 \\
\hline G2P transfers: open accounts & 103 & 0.320 & 0.469 & 0 & 1 \\
\hline Promoting savings, Savings scheme & 103 & 0.175 & 0.382 & 0 & 1 \\
\hline Promoting savings, Tax incentive scheme & 103 & 0.340 & 0.476 & 0 & 1 \\
\hline
\end{tabular}


Table 4: Financial inclusion indicators and individual characteristics

\begin{tabular}{|c|c|c|c|}
\hline & (1) & (2) & (3) \\
\hline Variable & Account & Savings & Frequency of use \\
\hline Model & Probit & Probit (selection) & Probit (selection) \\
\hline Country fixed effects & Yes & Yes & Yes \\
\hline Female & $\begin{array}{l}-0.027 \\
(0.022)\end{array}$ & $\begin{array}{l}-0.010 \\
(0.016)\end{array}$ & $\begin{array}{l}-0.091 * * * \\
(0.015)\end{array}$ \\
\hline Income: poorest $20 \%$ & $\begin{array}{l}-0.777 * * * \\
(0.036)\end{array}$ & $\begin{array}{l}-0.633 * * * \\
(0.040)\end{array}$ & $\begin{array}{l}-0.660 * * * \\
(0.047)\end{array}$ \\
\hline Income: second $20 \%$ & $\begin{array}{l}-0.616^{* * * *} \\
(0.032)\end{array}$ & $\begin{array}{l}-0.464 * * * \\
(0.031)\end{array}$ & $\begin{array}{l}-0.514 * * * \\
(0.042)\end{array}$ \\
\hline Income: middle $20 \%$ & $\begin{array}{l}-0.454 * * * \\
(0.028)\end{array}$ & $\begin{array}{l}-0.324 * * * \\
(0.029)\end{array}$ & $\begin{array}{l}-0.333 * * * \\
(0.037)\end{array}$ \\
\hline Income: fourth $20 \%$ & $\begin{array}{l}-0.279 * * * \\
(0.023)\end{array}$ & $\begin{array}{l}-0.186^{* * *} \\
(0.028)\end{array}$ & $\begin{array}{l}-0.253^{* * * *} \\
(0.029)\end{array}$ \\
\hline Age & $\begin{array}{l}0.038 * * * \\
(0.003)\end{array}$ & $\begin{array}{l}0.000 \\
(0.004)\end{array}$ & $\begin{array}{l}0.033 * * * \\
(0.004)\end{array}$ \\
\hline Age squared & $\begin{array}{l}-0.000^{* * * *} \\
(0.000)\end{array}$ & $\begin{array}{l}-0.000 \\
(0.000)\end{array}$ & $\begin{array}{l}-0.000 * * * \\
(0.000)\end{array}$ \\
\hline Rural & $\begin{array}{l}-0.156^{* * * *} \\
(0.025)\end{array}$ & $\begin{array}{l}-0.030 \\
(0.022)\end{array}$ & $\begin{array}{l}-0.133 * * * \\
(0.028)\end{array}$ \\
\hline $0-8$ years of education & $\begin{array}{l}-0.580 * * * \\
(0.027)\end{array}$ & $\begin{array}{l}-0.273 * * * \\
(0.029)\end{array}$ & $\begin{array}{l}-0.463 * * * \\
(0.031)\end{array}$ \\
\hline Log of household size & $\begin{array}{l}-0.139 * * * \\
(0.018)\end{array}$ & $\begin{array}{l}-0.127 * * * \\
(0.021)\end{array}$ & $\begin{array}{l}-0.157^{* * * *} \\
(0.019)\end{array}$ \\
\hline Married & $\begin{array}{l}0.107 * * * \\
(0.021)\end{array}$ & $\begin{array}{l}0.062 * * \\
(0.025)\end{array}$ & $\begin{array}{l}0.098 * * * \\
(0.021)\end{array}$ \\
\hline Divorced/Separated & $\begin{array}{l}0.051 \\
(0.035)\end{array}$ & $\begin{array}{l}-0.083 * * \\
(0.034)\end{array}$ & $\begin{array}{l}0.089 * * * \\
(0.033)\end{array}$ \\
\hline Employed for employer & $\begin{array}{l}0.329 * * * \\
(0.032)\end{array}$ & $\begin{array}{l}-0.034 \\
(0.026)\end{array}$ & $\begin{array}{l}0.146 * * * \\
(0.037)\end{array}$ \\
\hline Unemployed & $\begin{array}{l}-0.328 * * * \\
(0.035)\end{array}$ & $\begin{array}{l}-0.518^{* * * *} \\
(0.041)\end{array}$ & $\begin{array}{l}-0.349 * * * \\
(0.051)\end{array}$ \\
\hline Out of workforce & $\begin{array}{l}-0.365^{* * * *} \\
(0.030)\end{array}$ & $\begin{array}{l}-0.332 * * * * \\
(0.034)\end{array}$ & $\begin{array}{l}-0.303 * * * \\
(0.033)\end{array}$ \\
\hline Constant & $\begin{array}{l}-0.849 * * * \\
(0.068)\end{array}$ & $\begin{array}{l}-0.258^{*} \\
(0.137)\end{array}$ & $\begin{array}{l}-1.333 * * * \\
(0.171)\end{array}$ \\
\hline Observations & 125,073 & 59,923 & 59,923 \\
\hline
\end{tabular}

Each column represents the estimation results of a regression of a financial inclusion indicator on country fixed effects and a set of individual characteristics. These financial inclusion indicators are as follows. Account refers to adults reported to currently have a bank account at a formal financial institution. Savings refers to adults reported to have saved or set aside money in the past 12 months using a financial institution. Finally, frequency of use refers to adults reported to have taken money out of their personal account(s) 3 or more times in a typical month. The exact definitions and data sources are in Table 2. Standard errors are in parentheses and are clustered at the country level. ***, **, and * denote significance at the 1\%, 5\%, and $10 \%$ level, respectively. 


\section{Table 5: Financial inclusion indicators and country characteristics}

\begin{tabular}{|c|c|c|c|}
\hline & (1) & (2) & (3) \\
\hline Variable & Account & Savings & Frequency of Use \\
\hline Model & Probit & Probit (selection) & Probit (selection) \\
\hline Individual determinants & Yes & Yes & Yes \\
\hline Controlled for log GDP per capita & Yes & Yes & Yes \\
\hline Costs of opening a bank account & $\begin{array}{l}-0.426 * * \\
(0.175)\end{array}$ & $\begin{array}{l}-0.158 \\
(0.122)\end{array}$ & $\begin{array}{l}-0.367 * * \\
(0.155)\end{array}$ \\
\hline Costs of maintaining a bank account & $\begin{array}{l}-0.440 * * * \\
(0.137)\end{array}$ & $\begin{array}{l}-0.209 * \\
(0.112)\end{array}$ & $\begin{array}{l}-0.221 \\
(0.140)\end{array}$ \\
\hline Costs of direct credit & $\begin{array}{l}-0.469 * * * \\
(0.140)\end{array}$ & $\begin{array}{l}-0.261 * * \\
(0.113)\end{array}$ & $\begin{array}{l}-0.294 * * \\
(0.144)\end{array}$ \\
\hline Costs of debit cards & $\begin{array}{l}-0.350 * * \\
(0.172)\end{array}$ & $\begin{array}{l}-0.233 \\
(0.153)\end{array}$ & $\begin{array}{l}-0.328 * \\
(0.186)\end{array}$ \\
\hline Offer basic or low fee account & $\begin{array}{l}-0.020 \\
(0.215)\end{array}$ & $\begin{array}{l}-0.044 \\
(0.122)\end{array}$ & $\begin{array}{l}0.077 \\
(0.154)\end{array}$ \\
\hline Principle component of KYC requirements & $\begin{array}{l}-0.023 \\
(0.037)\end{array}$ & $\begin{array}{l}-0.014 \\
(0.030)\end{array}$ & $\begin{array}{l}-0.052 \\
(0.037)\end{array}$ \\
\hline Exception from $\mathrm{KYC}$ requirements & $\begin{array}{l}0.120 \\
(0.165)\end{array}$ & $\begin{array}{l}0.050 \\
(0.117)\end{array}$ & $\begin{array}{l}0.022 \\
(0.141)\end{array}$ \\
\hline Branch penetration (geographic) & $\begin{array}{l}0.007 * * * \\
(0.002) \\
\end{array}$ & $\begin{array}{l}0.002 * \\
(0.001) \\
\end{array}$ & $\begin{array}{l}0.001 \\
(0.001) \\
\end{array}$ \\
\hline ATM penetration (geographic) & $\begin{array}{l}0.002 \text { *** } \\
(0.001)\end{array}$ & $\begin{array}{l}0.001 * * \\
(0.000)\end{array}$ & $\begin{array}{l}0.000 \\
(0.000)\end{array}$ \\
\hline Interoperability POSs & $\begin{array}{l}-0.162 \\
(0.102)\end{array}$ & $\begin{array}{l}0.005 \\
(0.081)\end{array}$ & $\begin{array}{l}-0.230^{* * *} \\
(0.101)\end{array}$ \\
\hline Correspondent banking permitted & $\begin{array}{l}0.178 \\
(0.129)\end{array}$ & $\begin{array}{l}0.092 \\
(0.102)\end{array}$ & $\begin{array}{l}0.139 \\
(0.115)\end{array}$ \\
\hline Promoting access in rural areas & $\begin{array}{l}-0.057 \\
(0.146)\end{array}$ & $\begin{array}{l}0.076 \\
(0.127)\end{array}$ & $\begin{array}{l}-0.035 \\
(0.135)\end{array}$ \\
\hline Share of member banks' deposits covered & $\begin{array}{l}0.005 \\
(0.003)\end{array}$ & $\begin{array}{l}0.001 \\
(0.002)\end{array}$ & $\begin{array}{l}0.002 \\
(0.003)\end{array}$ \\
\hline Total disclosure requirements for deposits & $\begin{array}{l}-0.042 * \\
(0.022)\end{array}$ & $\begin{array}{l}-0.033^{* *} \\
(0.016)\end{array}$ & $\begin{array}{l}-0.023 \\
(0.028)\end{array}$ \\
\hline Consumer protection: Monitoring index & $\begin{array}{l}-0.025 \\
(0.041)\end{array}$ & $\begin{array}{l}-0.002 \\
(0.031)\end{array}$ & $\begin{array}{l}0.003 \\
(0.032)\end{array}$ \\
\hline Consumer protection: Enforcement index & $\begin{array}{l}0.030 \\
(0.028) \\
\end{array}$ & $\begin{array}{l}-0.001 \\
(0.024)\end{array}$ & $\begin{array}{l}0.041 \\
(0.025) \\
\end{array}$ \\
\hline Asset share of government controlled banks & $\begin{array}{l}-0.001 \\
(0.004)\end{array}$ & $\begin{array}{l}-0.005^{*} \\
(0.003)\end{array}$ & $\begin{array}{l}-0.004 \\
(0.004)\end{array}$ \\
\hline Asset share of foreign controlled banks & $\begin{array}{l}-0.000 \\
(0.002)\end{array}$ & $\begin{array}{l}0.001 \\
(0.002)\end{array}$ & $\begin{array}{l}0.008 \\
(0.000)\end{array}$ \\
\hline Legal rights index & $\begin{array}{l}0.085 * * * \\
(0.018)\end{array}$ & $\begin{array}{l}0.061 * * * \\
(0.016)\end{array}$ & $\begin{array}{l}0.079 * * * \\
(0.024)\end{array}$ \\
\hline Political risk rating & $\begin{array}{l}0.033^{* * * *} \\
(0.009) \\
\end{array}$ & $\begin{array}{l}0.024 * * * \\
(0.007)\end{array}$ & $\begin{array}{l}0.056^{* * * *} \\
(0.011) \\
\end{array}$ \\
\hline G2P transfers: open accounts & $\begin{array}{l}0.146 \\
(0.147)\end{array}$ & $\begin{array}{l}0.094 \\
(0.092)\end{array}$ & $\begin{array}{l}0.238^{*} \\
(0.143)\end{array}$ \\
\hline Promoting savings, Savings scheme & $\begin{array}{l}0.098 \\
(0.179)\end{array}$ & $\begin{array}{l}0.041 \\
(0.103)\end{array}$ & $\begin{array}{l}0.253^{*} \\
(0.151)\end{array}$ \\
\hline Promoting savings, Tax incentive scheme & $\begin{array}{l}0.318 * * \\
(0.130)\end{array}$ & $\begin{array}{l}0.117 \\
(0.106)\end{array}$ & $\begin{array}{l}0.240^{*} \\
(0.122)\end{array}$ \\
\hline
\end{tabular}

Each cell represents the estimation result of a separate regression of a financial inclusion indicator on the individual characteristics in Table 4, the log of GDP per capita, and a country characteristic. These financial inclusion indicators are as follows. Account refers to adults reported to currently have a bank account at a formal financial institution. Savings refers to adults reported to have saved or set aside money in the past 12 months using a financial institution. Finally, frequency of use refers to adults reported to have taken money out of their personal account(s) 3 or more times in a typical month. The exact definitions and data sources are in Table 2. Standard errors are in parentheses and are clustered at the country level. $* * *, * *$, and $*$ denote significance at the $1 \%$, $5 \%$, and $10 \%$ level, respectively. 
Table 6: IV estimations for the likelihood of owning an account

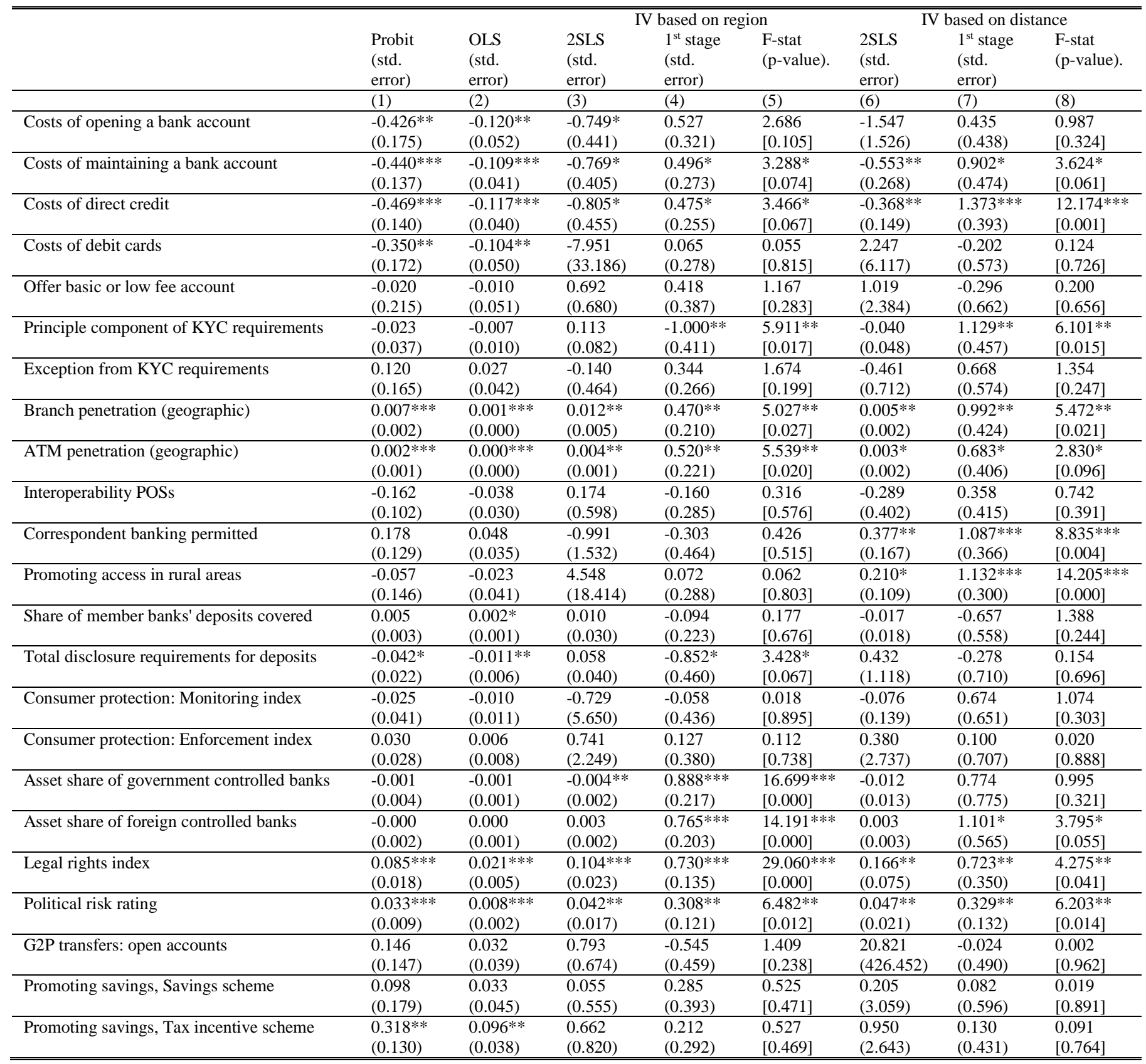

Column (1) repeats the estimation results in column (1) of Table 5. The estimation results of the linear probability model are given in Column (2) for comparison. Columns (3), (4), and (5) correspond to the 2SLS estimation where instruments are based on the region. Column (3) presents the second stage estimation results, column (4) presents the coefficient of the first stage estimations, and column (5) provides the corresponding F statistics. Columns (6), (7), and (8) replicate columns (3)-(5) but using the instruments that are based on distance. Standard errors are provided within parentheses and are clustered at the country level (in all columns other than (5) and (8)). The $p$ values corresponding to the $F$ statistics are given within brackets in columns (5) and (8). ***, **, and * denote significance at the $1 \%, 5 \%$, and $10 \%$ level, respectively. 
Table 7: Interactions for the likelihood of account ownership

\begin{tabular}{|c|c|c|c|c|}
\hline Interacted with: & $\begin{array}{l}(1) \\
\text { rural }\end{array}$ & $\begin{array}{l}(2) \\
\text { poorest } 20 \%\end{array}$ & $\begin{array}{l}\text { (3) } \\
\text { female }\end{array}$ & $\begin{array}{l}(4) \\
\text { age } 15-24\end{array}$ \\
\hline Individual determinants & Yes & Yes & Yes & Yes \\
\hline Controlled for country fixed effects & Yes & Yes & Yes & Yes \\
\hline Costs of opening a bank account & $\begin{array}{l}-0.126^{*} \\
(0.066) \\
\end{array}$ & $\begin{array}{l}-0.097 \\
(0.068) \\
\end{array}$ & $\begin{array}{l}0.015 \\
(0.054)\end{array}$ & $\begin{array}{l}0.040 \\
(0.061)\end{array}$ \\
\hline Costs of maintaining a bank account & $\begin{array}{l}0.042 \\
(0.063)\end{array}$ & $\begin{array}{l}-0.016 \\
(0.061)\end{array}$ & $\begin{array}{l}-0.059 \\
(0.078)\end{array}$ & $\begin{array}{l}-0.131 * * \\
(0.061)\end{array}$ \\
\hline Costs of direct credit & $\begin{array}{l}-0.025 \\
(0.065)\end{array}$ & $\begin{array}{l}0.028 \\
(0.066)\end{array}$ & $\begin{array}{l}0.059 \\
(0.061)\end{array}$ & $\begin{array}{l}-0.125^{*} \\
(0.065)\end{array}$ \\
\hline Costs of debit cards & $\begin{array}{l}-0.010 \\
(0.065)\end{array}$ & $\begin{array}{l}-0.055 \\
(0.070)\end{array}$ & $\begin{array}{l}-0.203^{* *} \\
(0.100)\end{array}$ & $\begin{array}{l}-0.100 \\
(0.073)\end{array}$ \\
\hline Offer basic or low fee account & $\begin{array}{l}0.187 * * \\
(0.078)\end{array}$ & $\begin{array}{l}0.002 \\
(0.058)\end{array}$ & $\begin{array}{l}-0.053 \\
(0.060)\end{array}$ & $\begin{array}{l}-0.035 \\
(0.080)\end{array}$ \\
\hline Principle component of KYC requirements & $\begin{array}{l}-0.014 \\
(0.016) \\
\end{array}$ & $\begin{array}{l}-0.017 \\
(0.019) \\
\end{array}$ & $\begin{array}{l}0.001 \\
(0.014) \\
\end{array}$ & $\begin{array}{l}0.013 \\
(0.017) \\
\end{array}$ \\
\hline Exception from $\mathrm{KYC}$ requirements & $\begin{array}{l}0.124 * \\
(0.068) \\
\end{array}$ & $\begin{array}{l}-0.054 \\
(0.049) \\
\end{array}$ & $\begin{array}{l}0.003 \\
(0.058) \\
\end{array}$ & $\begin{array}{l}0.007 \\
(0.067) \\
\end{array}$ \\
\hline Branch penetration (geographic) & $\begin{array}{l}0.003^{* * * *} \\
(0.001)\end{array}$ & $\begin{array}{l}0.001 \text { ** } \\
(0.001) \\
\end{array}$ & $\begin{array}{l}-0.000 \\
(0.001)\end{array}$ & $\begin{array}{l}-0.003 * * * * \\
(0.001)\end{array}$ \\
\hline ATM penetration (geographic) & $\begin{array}{l}0.000 \\
(0.000)\end{array}$ & $\begin{array}{l}0.000 \\
(0.000)\end{array}$ & $\begin{array}{l}0.000 \\
(0.000)\end{array}$ & $\begin{array}{l}-0.001 \text { *** } \\
(0.000)\end{array}$ \\
\hline Interoperability POSs & $\begin{array}{l}-0.034 \\
(0.037)\end{array}$ & $\begin{array}{l}-0.023 \\
(0.038)\end{array}$ & $\begin{array}{l}0.017 \\
(0.036)\end{array}$ & $\begin{array}{l}0.026 \\
(0.048)\end{array}$ \\
\hline Correspondent banking permitted & $\begin{array}{l}0.064 \\
(0.053)\end{array}$ & $\begin{array}{l}0.025 \\
(0.062)\end{array}$ & $\begin{array}{l}0.069 \\
(0.051)\end{array}$ & $\begin{array}{l}-0.003 \\
(0.061)\end{array}$ \\
\hline Promoting access in rural areas & $\begin{array}{l}-0.094 \\
(0.057)\end{array}$ & $\begin{array}{l}-0.057 \\
(0.052)\end{array}$ & $\begin{array}{l}0.002 \\
(0.048)\end{array}$ & $\begin{array}{l}0.073 \\
(0.058)\end{array}$ \\
\hline Share of member banks' deposits covered & $\begin{array}{l}0.001 \\
(0.001) \\
\end{array}$ & $\begin{array}{l}0.003^{* *} \\
(0.001) \\
\end{array}$ & $\begin{array}{l}0.001 \\
(0.001) \\
\end{array}$ & $\begin{array}{l}-0.001 \\
(0.002) \\
\end{array}$ \\
\hline Total disclosure requirements for deposits & $\begin{array}{l}0.018 \text { ** } \\
(0.009) \\
\end{array}$ & $\begin{array}{l}0.017^{*} \\
(0.009)\end{array}$ & $\begin{array}{l}0.006 \\
(0.009)\end{array}$ & $\begin{array}{l}-0.012 \\
(0.010) \\
\end{array}$ \\
\hline Consumer protection: Monitoring index & $\begin{array}{l}0.038 * * * \\
(0.014)\end{array}$ & $\begin{array}{l}0.006 \\
(0.018)\end{array}$ & $\begin{array}{l}-0.001 \\
(0.012)\end{array}$ & $\begin{array}{l}-0.023 \\
(0.017)\end{array}$ \\
\hline Consumer protection: Enforcement index & $\begin{array}{l}0.034 * * * \\
(0.011)\end{array}$ & $\begin{array}{l}0.011 \\
(0.015)\end{array}$ & $\begin{array}{l}-0.004 \\
(0.010)\end{array}$ & $\begin{array}{l}-0.015 \\
(0.013)\end{array}$ \\
\hline Asset share of government controlled banks & $\begin{array}{l}0.002 \\
(0.001)\end{array}$ & $\begin{array}{l}-0.001 \\
(0.001)\end{array}$ & $\begin{array}{l}-0.002 * \\
(0.001)\end{array}$ & $\begin{array}{l}0.004 * * * \\
(0.001)\end{array}$ \\
\hline Asset share of foreign controlled banks & $\begin{array}{l}-0.001 \\
(0.001)\end{array}$ & $\begin{array}{l}0.001 \\
(0.001)\end{array}$ & $\begin{array}{l}0.001 \\
(0.001)\end{array}$ & $\begin{array}{l}-0.000 \\
(0.001)\end{array}$ \\
\hline Legal rights index & $\begin{array}{l}-0.009 \\
(0.009)\end{array}$ & $\begin{array}{l}-0.006 \\
(0.007)\end{array}$ & $\begin{array}{l}0.009 \\
(0.008)\end{array}$ & $\begin{array}{l}0.017 \\
(0.011)\end{array}$ \\
\hline Political risk rating & $\begin{array}{l}0.011 \text { *** } \\
(0.003)\end{array}$ & $\begin{array}{l}0.006 * * \\
(0.002)\end{array}$ & $\begin{array}{l}0.004 * * \\
(0.002)\end{array}$ & $\begin{array}{l}-0.006^{*} \\
(0.003)\end{array}$ \\
\hline G2P transfers: open accounts & $\begin{array}{l}0.112 * \\
(0.057) \\
\end{array}$ & $\begin{array}{l}0.061 \\
(0.057) \\
\end{array}$ & $\begin{array}{l}-0.088 \\
(0.063) \\
\end{array}$ & $\begin{array}{l}-0.079 \\
(0.065) \\
\end{array}$ \\
\hline Promoting savings, Savings scheme & $\begin{array}{l}0.036 \\
(0.078)\end{array}$ & $\begin{array}{l}0.102 \\
(0.068)\end{array}$ & $\begin{array}{l}0.134 * * * \\
(0.051)\end{array}$ & $\begin{array}{l}-0.100 \\
(0.097)\end{array}$ \\
\hline Promoting savings, Tax incentive scheme & $\begin{array}{l}0.079 \\
(0.068)\end{array}$ & $\begin{array}{l}-0.003 \\
(0.074)\end{array}$ & $\begin{array}{l}-0.076 \\
(0.065)\end{array}$ & $\begin{array}{l}-0.121 \\
(0.079)\end{array}$ \\
\hline
\end{tabular}

Each cell represents the estimation result of a separate probit regression of account ownership on the individual characteristics in

Table 4, country fixed effects, and a country characteristic interacted with either rural, the poorest 20\%, female, or age 15-24. Account ownership refers to adults reported to currently have a bank account at a formal financial institution. The exact definitions and data sources are in Table 2 . Standard errors are in parentheses and are clustered at the country level. ***, **, and * denote significance at the $1 \%, 5 \%$, and $10 \%$ level, respectively. In column (4), the individual level, age and age squared are replaced with the age categories 15-24, 25-64, and 65 and up. 
Table 8: Interactions for the likelihood of saving with an account

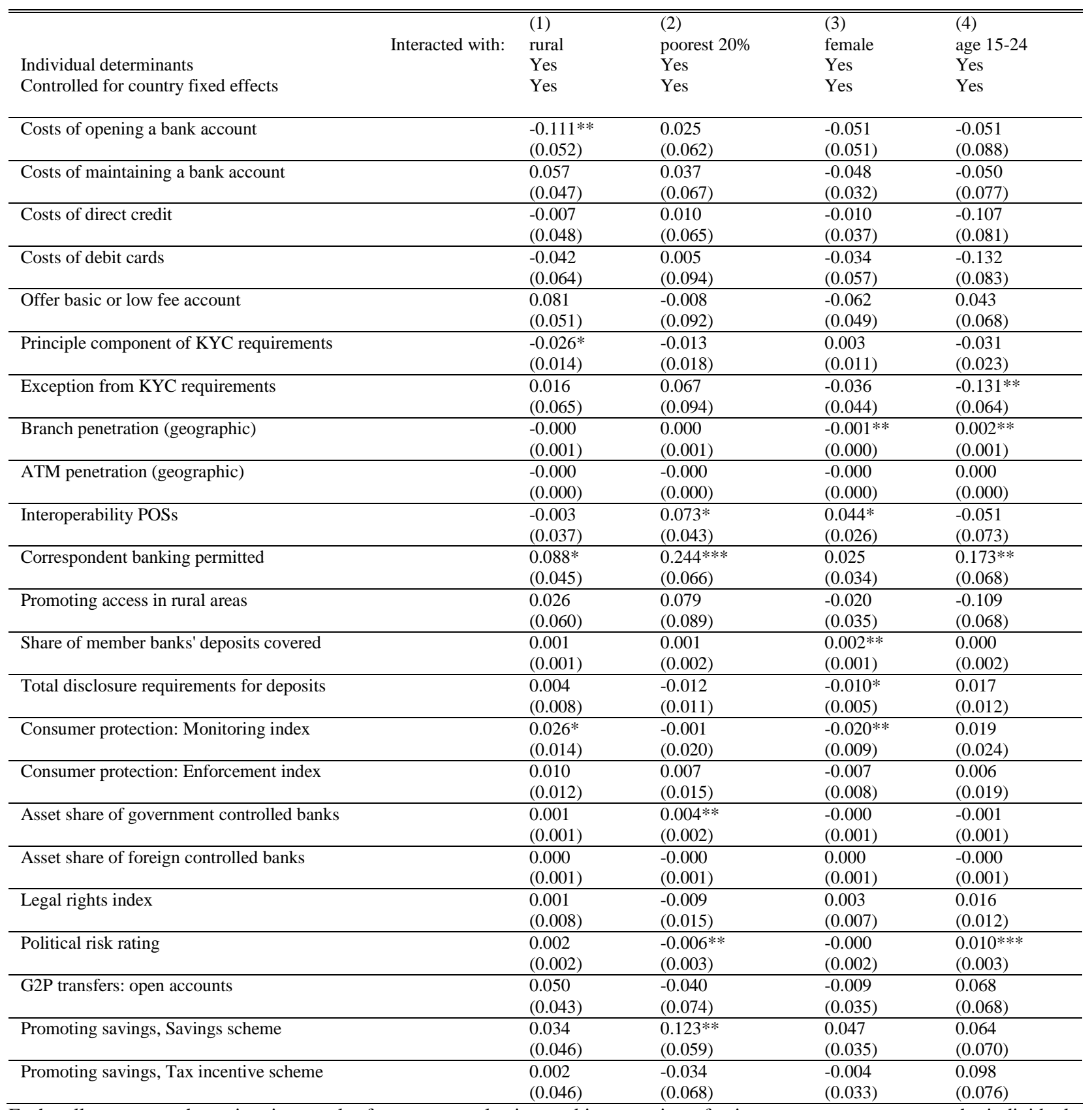

Each cell represents the estimation result of a separate selection probit regression of using an account to save on the individual characteristics in Table 4, country fixed effects, and a country characteristic interacted with either rural, the poorest $20 \%$, female, or age 15-24. Using an account to save refers to adults reported to have saved or set aside money in the past 12 months using a financial institution. The exact definitions and data sources are in Table 2. Standard errors are in parentheses and are clustered at the country level. $* * *, * *$, and $*$ denote significance at the $1 \%, 5 \%$, and $10 \%$ level, respectively. In column (4), the individual level, age and age squared are replaced with the age categories 15-24, 25-64, and 65 and up. 
Table 9: Interactions for the frequency of account use

\begin{tabular}{|c|c|c|c|c|}
\hline Interacted with: & $\begin{array}{l}1) \\
\text { rural }\end{array}$ & $\begin{array}{l}(2) \\
\text { poorest } 20 \%\end{array}$ & $\begin{array}{l}3) \\
\text { female }\end{array}$ & $\begin{array}{l}(4) \\
\text { age 15-24 }\end{array}$ \\
\hline Individual determinants & Yes & Yes & Yes & Yes \\
\hline Controlled for country fixed effects & Yes & Yes & Yes & Yes \\
\hline Costs of opening a bank account & $\begin{array}{l}-0.111 \\
(0.091)\end{array}$ & $\begin{array}{l}-0.105 \\
(0.105) \\
\end{array}$ & $\begin{array}{l}-0.006 \\
(0.068) \\
\end{array}$ & $\begin{array}{l}0.065 \\
(0.100) \\
\end{array}$ \\
\hline Costs of maintaining a bank account & $\begin{array}{l}-0.004 \\
(0.064) \\
\end{array}$ & $\begin{array}{l}-0.019 \\
(0.060) \\
\end{array}$ & $\begin{array}{l}-0.009 \\
(0.043) \\
\end{array}$ & $\begin{array}{l}0.045 \\
(0.108) \\
\end{array}$ \\
\hline Costs of direct credit & $\begin{array}{l}-0.093 \\
(0.066) \\
\end{array}$ & $\begin{array}{l}-0.027 \\
(0.065) \\
\end{array}$ & $\begin{array}{l}0.030 \\
(0.038) \\
\end{array}$ & $\begin{array}{l}0.001 \\
(0.104) \\
\end{array}$ \\
\hline Costs of debit cards & $\begin{array}{l}0.115 \\
(0.078)\end{array}$ & $\begin{array}{l}-0.013 \\
(0.098)\end{array}$ & $\begin{array}{l}-0.095 \\
(0.066)\end{array}$ & $\begin{array}{l}0.149 \\
(0.096)\end{array}$ \\
\hline Offer basic or low fee account & $\begin{array}{l}0.084 \\
(0.098) \\
\end{array}$ & $\begin{array}{l}0.043 \\
(0.086) \\
\end{array}$ & $\begin{array}{l}-0.059 \\
(0.040) \\
\end{array}$ & $\begin{array}{l}-0.276^{* *} \\
(0.126) \\
\end{array}$ \\
\hline Principle component of KYC requirements & $\begin{array}{l}-0.025 \\
(0.017)\end{array}$ & $\begin{array}{l}-0.018 \\
(0.018)\end{array}$ & $\begin{array}{l}-0.014 \\
(0.010)\end{array}$ & $\begin{array}{l}0.053 * * \\
(0.023)\end{array}$ \\
\hline Exception from KYC requirements & $\begin{array}{l}-0.028 \\
(0.069) \\
\end{array}$ & $\begin{array}{l}-0.193 * * \\
(0.087) \\
\end{array}$ & $\begin{array}{l}0.013 \\
(0.039) \\
\end{array}$ & $\begin{array}{l}-0.084 \\
(0.098) \\
\end{array}$ \\
\hline Branch penetration (geographic) & $\begin{array}{l}0.001 * * \\
(0.001)\end{array}$ & $\begin{array}{l}0.000 \\
(0.001) \\
\end{array}$ & $\begin{array}{l}-0.001 * * \\
(0.000)\end{array}$ & $\begin{array}{l}-0.002 * * \\
(0.001)\end{array}$ \\
\hline ATM penetration (geographic) & $\begin{array}{l}0.000^{* * *} \\
(0.000)\end{array}$ & $\begin{array}{l}-0.000 \\
(0.000)\end{array}$ & $\begin{array}{l}-0.000^{*} \\
(0.000) \\
\end{array}$ & $\begin{array}{l}-0.000 \\
(0.000)\end{array}$ \\
\hline Interoperability POSs & $\begin{array}{l}-0.049 \\
(0.042)\end{array}$ & $\begin{array}{l}-0.050 \\
(0.038)\end{array}$ & $\begin{array}{l}-0.021 \\
(0.020)\end{array}$ & $\begin{array}{l}0.097 * * \\
(0.049) \\
\end{array}$ \\
\hline Correspondent banking permitted & $\begin{array}{l}-0.044 \\
(0.059)\end{array}$ & $\begin{array}{l}0.071 \\
(0.056)\end{array}$ & $\begin{array}{l}0.009 \\
(0.035)\end{array}$ & $\begin{array}{l}-0.041 \\
(0.076)\end{array}$ \\
\hline Promoting access in rural areas & $\begin{array}{l}-0.118^{*} \\
(0.065)\end{array}$ & $\begin{array}{l}-0.052 \\
(0.076)\end{array}$ & $\begin{array}{l}0.051 \\
(0.033)\end{array}$ & $\begin{array}{l}0.078 \\
(0.076)\end{array}$ \\
\hline Share of member banks' deposits covered & $\begin{array}{l}-0.000 \\
(0.001)\end{array}$ & $\begin{array}{l}0.002 \\
(0.001)\end{array}$ & $\begin{array}{l}0.001 \\
(0.001) \\
\end{array}$ & $\begin{array}{l}0.003 \\
(0.002)\end{array}$ \\
\hline Total disclosure requirements for deposits & $\begin{array}{l}0.001 \\
(0.009)\end{array}$ & $\begin{array}{l}0.004 \\
(0.008) \\
\end{array}$ & $\begin{array}{l}0.003 \\
(0.005) \\
\end{array}$ & $\begin{array}{l}-0.025^{* * *} \\
(0.012) \\
\end{array}$ \\
\hline Consumer protection: Monitoring index & $\begin{array}{l}0.020 \\
(0.018) \\
\end{array}$ & $\begin{array}{l}0.003 \\
(0.019) \\
\end{array}$ & $\begin{array}{l}-0.007 \\
(0.009) \\
\end{array}$ & $\begin{array}{l}-0.027 \\
(0.022) \\
\end{array}$ \\
\hline Consumer protection: Enforcement index & $\begin{array}{l}0.032 * * \\
(0.012)\end{array}$ & $\begin{array}{l}0.007 \\
(0.015)\end{array}$ & $\begin{array}{l}-0.010 \\
(0.008)\end{array}$ & $\begin{array}{l}-0.019 \\
(0.019)\end{array}$ \\
\hline Asset share of government controlled banks & $\begin{array}{l}-0.001 \\
(0.001)\end{array}$ & $\begin{array}{l}-0.001 \\
(0.001)\end{array}$ & $\begin{array}{l}0.001 \\
(0.001)\end{array}$ & $\begin{array}{l}0.002 * \\
(0.001)\end{array}$ \\
\hline Asset share of foreign controlled banks & $\begin{array}{l}0.001 \\
(0.001)\end{array}$ & $\begin{array}{l}0.000 \\
(0.001)\end{array}$ & $\begin{array}{l}0.000 \\
(0.001)\end{array}$ & $\begin{array}{l}-0.000 \\
(0.001)\end{array}$ \\
\hline Legal rights index & $\begin{array}{l}-0.002 \\
(0.012)\end{array}$ & $\begin{array}{l}-0.020 * \\
(0.012)\end{array}$ & $\begin{array}{l}-0.001 \\
(0.006)\end{array}$ & $\begin{array}{l}0.004 \\
(0.015)\end{array}$ \\
\hline Political risk rating & $\begin{array}{l}0.009 * * * \\
(0.002)\end{array}$ & $\begin{array}{l}0.000 \\
(0.003) \\
\end{array}$ & $\begin{array}{l}-0.001 \\
(0.002) \\
\end{array}$ & $\begin{array}{l}-0.014 * * * \\
(0.003)\end{array}$ \\
\hline G2P transfers: open accounts & $\begin{array}{l}0.088 \\
(0.057) \\
\end{array}$ & $\begin{array}{l}0.043 \\
(0.059) \\
\end{array}$ & $\begin{array}{l}0.013 \\
(0.036) \\
\end{array}$ & $\begin{array}{l}-0.239 \text { *** } \\
(0.081)\end{array}$ \\
\hline Promoting savings, Savings scheme & $\begin{array}{l}0.027 \\
(0.082) \\
\end{array}$ & $\begin{array}{l}0.016 \\
(0.058) \\
\end{array}$ & $\begin{array}{l}0.053 \\
(0.036) \\
\end{array}$ & $\begin{array}{l}-0.099 \\
(0.098) \\
\end{array}$ \\
\hline Promoting savings, Tax incentive scheme & $\begin{array}{l}0.033 \\
(0.062)\end{array}$ & $\begin{array}{l}-0.021 \\
(0.062)\end{array}$ & $\begin{array}{l}0.015 \\
(0.034)\end{array}$ & $\begin{array}{l}-0.113 \\
(0.080)\end{array}$ \\
\hline
\end{tabular}

Each cell represents the estimation result of a separate selection probit regression of frequency of use on the individual characteristics in Table 4, country fixed effects, and a country characteristic interacted with either rural, the poorest $20 \%$, female, or age 15-24. Frequency of use refers to adults reported to have taken money out of their personal account(s) 3 or more times in a typical month. The exact definitions and data sources are in Table 2. Standard errors are in parentheses and are clustered at the country level. ***,**, and * denote significance at the $1 \%, 5 \%$, and $10 \%$ level, respectively. In column (4), the individual level, age and age squared are replaced with the age categories 15-24, 25-64, and 65 and up. 


\section{Table 10: Perceived barriers to account ownership and individual characteristics}

\begin{tabular}{|c|c|c|c|c|c|c|}
\hline & (1) & (2) & (3) & (4) & (5) & (6) \\
\hline Variable & Too expensive & $\begin{array}{c}\text { Lack of } \\
\text { necessary } \\
\text { documentation }\end{array}$ & $\begin{array}{c}\text { Too far } \\
\text { away }\end{array}$ & No trust & $\begin{array}{l}\text { Not enough } \\
\text { money }\end{array}$ & $\begin{array}{l}\text { Not enough } \\
\text { money } \\
\text { only reason }\end{array}$ \\
\hline Country fixed effects & Yes & Yes & Yes & Yes & Yes & Yes \\
\hline Female & $\begin{array}{l}-0.017 \\
(0.015)\end{array}$ & $\begin{array}{l}-0.027 \\
(0.019)\end{array}$ & $\begin{array}{l}0.002 \\
(0.019)\end{array}$ & $\begin{array}{l}-0.061 * * * \\
(0.016)\end{array}$ & $\begin{array}{l}-0.010 \\
(0.016)\end{array}$ & $\begin{array}{l}0.024 \\
(0.016)\end{array}$ \\
\hline Income: poorest $20 \%$ & $\begin{array}{l}0.254 * * * \\
(0.049)\end{array}$ & $\begin{array}{l}-0.013 \\
(0.053)\end{array}$ & $\begin{array}{l}0.115 * * \\
(0.055)\end{array}$ & $\begin{array}{l}0.009 \\
(0.041)\end{array}$ & $\begin{array}{l}0.342 * * * \\
(0.053)\end{array}$ & $\begin{array}{l}0.152^{* * * *} \\
(0.046)\end{array}$ \\
\hline Income: second $20 \%$ & $\begin{array}{l}0.222^{* * * *} \\
(0.035)\end{array}$ & $\begin{array}{l}-0.002 \\
(0.048)\end{array}$ & $\begin{array}{l}0.097 * * \\
(0.046)\end{array}$ & $\begin{array}{l}0.038 \\
(0.040)\end{array}$ & $\begin{array}{l}0.268 * * * \\
(0.039)\end{array}$ & $\begin{array}{l}0.075^{*} \\
(0.040)\end{array}$ \\
\hline Income: middle $20 \%$ & $\begin{array}{l}0.157 * * * \\
(0.037)\end{array}$ & $\begin{array}{l}0.034 \\
(0.042)\end{array}$ & $\begin{array}{l}0.094 * * \\
(0.039)\end{array}$ & $\begin{array}{l}0.063 \\
(0.039)\end{array}$ & $\begin{array}{l}0.157 * * * \\
(0.030)\end{array}$ & $\begin{array}{l}0.011 \\
(0.030)\end{array}$ \\
\hline Income: fourth $20 \%$ & $\begin{array}{l}0.145^{* * * *} \\
(0.029)\end{array}$ & $\begin{array}{l}0.015 \\
(0.039)\end{array}$ & $\begin{array}{l}0.043 \\
(0.035)\end{array}$ & $\begin{array}{l}0.082 * * \\
(0.034)\end{array}$ & $\begin{array}{l}0.088 * * * \\
(0.025)\end{array}$ & $\begin{array}{l}-0.027 \\
(0.028)\end{array}$ \\
\hline Age & $\begin{array}{l}0.004 \\
(0.003)\end{array}$ & $\begin{array}{l}-0.017 * * * \\
(0.004)\end{array}$ & $\begin{array}{l}-0.002 \\
(0.003)\end{array}$ & $\begin{array}{l}0.006 * \\
(0.003)\end{array}$ & $\begin{array}{l}0.009 * * * \\
(0.003)\end{array}$ & $\begin{array}{l}0.010 * * * \\
(0.003)\end{array}$ \\
\hline Age squared & $\begin{array}{l}-0.000 \\
(0.000)\end{array}$ & $\begin{array}{l}0.000^{* * * *} \\
(0.000)\end{array}$ & $\begin{array}{l}0.000 \\
(0.000)\end{array}$ & $\begin{array}{l}-0.000 \\
(0.000)\end{array}$ & $\begin{array}{l}-0.000^{* *} \\
(0.000)\end{array}$ & $\begin{array}{l}-0.000 * * \\
(0.000)\end{array}$ \\
\hline Rural & $\begin{array}{l}0.074 * * \\
(0.032)\end{array}$ & $\begin{array}{l}0.072 * * \\
(0.033)\end{array}$ & $\begin{array}{l}0.560 * * * \\
(0.045)\end{array}$ & $\begin{array}{l}0.017 \\
(0.028)\end{array}$ & $\begin{array}{l}-0.007 \\
(0.027)\end{array}$ & $\begin{array}{l}-0.110^{* * * *} \\
(0.027)\end{array}$ \\
\hline $0-8$ years of education & $\begin{array}{l}0.082 * * * \\
(0.030)\end{array}$ & $\begin{array}{l}0.112 * * * \\
(0.041)\end{array}$ & $\begin{array}{l}0.119 * * * \\
(0.030)\end{array}$ & $\begin{array}{l}0.037 \\
(0.033)\end{array}$ & $\begin{array}{l}0.016 \\
(0.029)\end{array}$ & $\begin{array}{l}-0.051 * \\
(0.029)\end{array}$ \\
\hline Log of household size & $\begin{array}{l}0.052 * * * \\
(0.019)\end{array}$ & $\begin{array}{l}0.003 \\
(0.021)\end{array}$ & $\begin{array}{l}0.027 \\
(0.023)\end{array}$ & $\begin{array}{l}0.007 \\
(0.021)\end{array}$ & $\begin{array}{l}0.047 * * \\
(0.019)\end{array}$ & $\begin{array}{l}-0.007 \\
(0.015)\end{array}$ \\
\hline Married & $\begin{array}{l}-0.009 \\
(0.022)\end{array}$ & $\begin{array}{l}-0.079 * * * \\
(0.024)\end{array}$ & $\begin{array}{l}0.046 * * \\
(0.022)\end{array}$ & $\begin{array}{l}0.025 \\
(0.021)\end{array}$ & $\begin{array}{l}-0.026 \\
(0.018)\end{array}$ & $\begin{array}{l}0.001 \\
(0.020)\end{array}$ \\
\hline Divorced/Separated & $\begin{array}{l}0.100 * * * \\
(0.037)\end{array}$ & $\begin{array}{l}-0.050 \\
(0.044)\end{array}$ & $\begin{array}{l}0.049 \\
(0.042)\end{array}$ & $\begin{array}{l}0.075 * \\
(0.039)\end{array}$ & $\begin{array}{l}0.041 \\
(0.034)\end{array}$ & $\begin{array}{l}0.003 \\
(0.036)\end{array}$ \\
\hline Employed for employer & $\begin{array}{l}-0.002 \\
(0.036)\end{array}$ & $\begin{array}{l}0.031 \\
(0.039)\end{array}$ & $\begin{array}{l}-0.023 \\
(0.031)\end{array}$ & $\begin{array}{l}-0.036 \\
(0.035)\end{array}$ & $\begin{array}{l}0.039 \\
(0.048)\end{array}$ & $\begin{array}{l}0.059 \\
(0.037)\end{array}$ \\
\hline Unemployed & $\begin{array}{l}0.086 * * \\
(0.041)\end{array}$ & $\begin{array}{l}0.012 \\
(0.047)\end{array}$ & $\begin{array}{l}-0.151 * * * \\
(0.042)\end{array}$ & $\begin{array}{l}0.067 * \\
(0.036)\end{array}$ & $\begin{array}{l}0.077 * \\
(0.040)\end{array}$ & $\begin{array}{l}0.092 * * \\
(0.038)\end{array}$ \\
\hline Out of workforce & $\begin{array}{l}-0.069 * \\
(0.037)\end{array}$ & $\begin{array}{l}0.011 \\
(0.043)\end{array}$ & $\begin{array}{l}-0.153 * * * \\
(0.033)\end{array}$ & $\begin{array}{l}-0.076^{* * * *} \\
(0.028)\end{array}$ & $\begin{array}{l}-0.073 * * * \\
(0.027)\end{array}$ & $\begin{array}{l}0.021 \\
(0.030)\end{array}$ \\
\hline Constant & $\begin{array}{l}-0.858^{* * *} \\
(0.086)\end{array}$ & $\begin{array}{l}-0.039 \\
(0.125)\end{array}$ & $\begin{array}{l}-0.943 * * * \\
(0.113)\end{array}$ & $\begin{array}{l}-0.578 * * * \\
(0.089)\end{array}$ & $\begin{array}{l}-0.649 * * * \\
(0.091)\end{array}$ & $\begin{array}{l}-2.356^{* * * *} \\
(0.093)\end{array}$ \\
\hline Observations & 65,262 & 64,573 & 65,178 & 65,251 & 65,387 & 65,185 \\
\hline
\end{tabular}

The sample includes only unbanked adults. Each column represents the estimation result of a regression of a perceived barrier to account ownership on country fixed effects and a set of individual characteristics. These account barriers are as follows. Too expensive refers to the respondents without an account that indicated "They are too expensive" as a reason. Lack of necessary documentation refers to the respondents without an account that indicated "You don't have the necessary documentation" as a reason. Too far away and no trust refers to the respondents without an account that indicated "Too far away" and "You don't trust them" as a reason, respectively. Finally, not enough money refers to the respondents without an account that indicated "Not enough money to use" as a reason. Note that respondent could give multiple reasons for not having an account. The exact definitions and data sources are in Table 2. Standard errors are in parentheses and are clustered at the country level. ***, **, and * denote significance at the $1 \%, 5 \%$, and $10 \%$ level, respectively. 
Table 11: Perceived barriers to account ownership and country characteristics

\begin{tabular}{|c|c|c|c|c|c|c|}
\hline & (1) & (2) & (3) & (4) & $(5)$ & (6) \\
\hline Variable & $\begin{array}{c}\text { Too } \\
\text { expensive }\end{array}$ & $\begin{array}{c}\text { Lack of } \\
\text { necessary } \\
\text { documentation }\end{array}$ & $\begin{array}{c}\text { Too far } \\
\text { away }\end{array}$ & No trust & $\begin{array}{c}\text { Not enough } \\
\text { money }\end{array}$ & $\begin{array}{c}\text { Not enough } \\
\text { money } \\
\text { only reason }\end{array}$ \\
\hline Controlled for log of GDP per capita & Yes & Yes & Yes & Yes & Yes & Yes \\
\hline Costs of opening a bank account & $\begin{array}{l}0.224 \\
(0.141)\end{array}$ & $\begin{array}{l}-0.053 \\
(0.127) \\
\end{array}$ & $\begin{array}{l}-0.020 \\
(0.169)\end{array}$ & $\begin{array}{l}0.111 \\
(0.111)\end{array}$ & $\begin{array}{l}-0.072 \\
(0.145)\end{array}$ & $\begin{array}{l}-0.143 \\
(0.179)\end{array}$ \\
\hline Costs of maintaining a bank account & $\begin{array}{l}0.347 \text { *** } \\
(0.122) \\
\end{array}$ & $\begin{array}{l}0.096 \\
(0.127) \\
\end{array}$ & $\begin{array}{l}0.164 \\
(0.109)\end{array}$ & $\begin{array}{l}0.088 \\
(0.105) \\
\end{array}$ & $\begin{array}{l}0.179 \\
(0.124)\end{array}$ & $\begin{array}{l}-0.147 \\
(0.106)\end{array}$ \\
\hline Costs of direct credit & $\begin{array}{l}0.165 \\
(0.140)\end{array}$ & $\begin{array}{l}-0.021 \\
(0.119)\end{array}$ & $\begin{array}{l}-0.113 \\
(0.134)\end{array}$ & $\begin{array}{l}0.133 \\
(0.108)\end{array}$ & $\begin{array}{l}0.232^{*} \\
(0.138)\end{array}$ & $\begin{array}{l}0.052 \\
(0.163)\end{array}$ \\
\hline Costs of debit cards & $\begin{array}{l}0.135 \\
(0.129)\end{array}$ & $\begin{array}{l}-0.012 \\
(0.127)\end{array}$ & $\begin{array}{l}0.087 \\
(0.144)\end{array}$ & $\begin{array}{l}0.082 \\
(0.113)\end{array}$ & $\begin{array}{l}-0.036 \\
(0.119) \\
\end{array}$ & $\begin{array}{l}-0.207^{*} \\
(0.124)\end{array}$ \\
\hline Offer basic or low fee account & $\begin{array}{l}0.124 \\
(0.162) \\
\end{array}$ & $\begin{array}{l}-0.029 \\
(0.081) \\
\end{array}$ & $\begin{array}{l}-0.038 \\
(0.082) \\
\end{array}$ & $\begin{array}{l}-0.038 \\
(0.137) \\
\end{array}$ & $\begin{array}{l}-0.167 \\
(0.102) \\
\end{array}$ & $\begin{array}{l}-0.210^{*} \\
(0.110) \\
\end{array}$ \\
\hline Principle component of KYC requirements & $\begin{array}{l}0.017 \\
(0.030)\end{array}$ & $\begin{array}{l}0.014 \\
(0.026)\end{array}$ & $\begin{array}{l}0.034 \\
(0.028)\end{array}$ & $\begin{array}{l}-0.014 \\
(0.021)\end{array}$ & $\begin{array}{l}0.029 \\
(0.026)\end{array}$ & $\begin{array}{l}0.012 \\
(0.025)\end{array}$ \\
\hline Exception from $\mathrm{KYC}$ requirements & $\begin{array}{l}0.122 \\
(0.120) \\
\end{array}$ & $\begin{array}{l}0.121 \\
(0.107) \\
\end{array}$ & $\begin{array}{l}-0.005 \\
(0.097) \\
\end{array}$ & $\begin{array}{l}-0.079 \\
(0.093) \\
\end{array}$ & $\begin{array}{l}-0.045 \\
(0.101) \\
\end{array}$ & $\begin{array}{l}-0.130 \\
(0.098) \\
\end{array}$ \\
\hline Branch penetration (geographic) & $\begin{array}{l}-0.004 * * \\
(0.002)\end{array}$ & $\begin{array}{l}-0.004 * \\
(0.002)\end{array}$ & $\begin{array}{l}-0.004^{*} \\
(0.002)\end{array}$ & $\begin{array}{l}-0.007 * * * \\
(0.001)\end{array}$ & $\begin{array}{l}-0.002 \\
(0.003)\end{array}$ & $\begin{array}{l}0.002 \\
(0.002)\end{array}$ \\
\hline ATM penetration (geographic) & $\begin{array}{l}-0.001 \\
(0.001) \\
\end{array}$ & $\begin{array}{l}-0.001 \\
(0.001) \\
\end{array}$ & $\begin{array}{l}-0.001 \\
(0.001) \\
\end{array}$ & $\begin{array}{l}-0.001 \\
(0.001) \\
\end{array}$ & $\begin{array}{l}0.000 \\
(0.001) \\
\end{array}$ & $\begin{array}{l}0.001^{*} \\
(0.000) \\
\end{array}$ \\
\hline Interoperability POSs & $\begin{array}{l}-0.012 \\
(0.067)\end{array}$ & $\begin{array}{l}0.014 \\
(0.056)\end{array}$ & $\begin{array}{l}-0.030 \\
(0.075)\end{array}$ & $\begin{array}{l}0.075 \\
(0.064)\end{array}$ & $\begin{array}{l}0.071 \\
(0.075)\end{array}$ & $\begin{array}{l}0.002 \\
(0.092)\end{array}$ \\
\hline Correspondent banking permitted & $\begin{array}{l}0.152 \\
(0.095)\end{array}$ & $\begin{array}{l}0.094 \\
(0.090)\end{array}$ & $\begin{array}{l}0.255^{* * * *} \\
(0.087)\end{array}$ & $\begin{array}{l}0.125 \\
(0.084)\end{array}$ & $\begin{array}{l}-0.093 \\
(0.092)\end{array}$ & $\begin{array}{l}-0.255^{* * * *} \\
(0.082)\end{array}$ \\
\hline Promoting access in rural areas & $\begin{array}{l}0.120 \\
(0.110)\end{array}$ & $\begin{array}{l}0.265^{* * * *} \\
(0.098)\end{array}$ & $\begin{array}{l}0.300 * * * \\
(0.094)\end{array}$ & $\begin{array}{l}-0.032 \\
(0.100)\end{array}$ & $\begin{array}{l}0.022 \\
(0.109)\end{array}$ & $\begin{array}{l}-0.166^{*} \\
(0.092)\end{array}$ \\
\hline Share of member banks' deposits covered & $\begin{array}{l}-0.005 * * \\
(0.003) \\
\end{array}$ & $\begin{array}{l}-0.003 \\
(0.003)\end{array}$ & $\begin{array}{l}-0.001 \\
(0.002)\end{array}$ & $\begin{array}{l}0.001 \\
(0.003)\end{array}$ & $\begin{array}{l}-0.000 \\
(0.003) \\
\end{array}$ & $\begin{array}{l}0.002 \\
(0.003)\end{array}$ \\
\hline Total disclosure requirements for deposits & $\begin{array}{l}-0.003 \\
(0.017)\end{array}$ & $\begin{array}{l}0.009 \\
(0.016)\end{array}$ & $\begin{array}{l}-0.009 \\
(0.015)\end{array}$ & $\begin{array}{l}0.021 \\
(0.014)\end{array}$ & $\begin{array}{l}-0.004 \\
(0.016)\end{array}$ & $\begin{array}{l}-0.016 \\
(0.016)\end{array}$ \\
\hline Consumer protection: Monitoring index & $\begin{array}{l}0.056 \\
(0.034) \\
\end{array}$ & $\begin{array}{l}0.048 \\
(0.029) \\
\end{array}$ & $\begin{array}{l}0.052 * * \\
(0.024) \\
\end{array}$ & $\begin{array}{l}0.027 \\
(0.035) \\
\end{array}$ & $\begin{array}{l}-0.018 \\
(0.034) \\
\end{array}$ & $\begin{array}{l}-0.066^{* * * *} \\
(0.021)\end{array}$ \\
\hline Consumer protection: Enforcement index & $\begin{array}{l}-0.009 \\
(0.022)\end{array}$ & $\begin{array}{l}-0.002 \\
(0.022)\end{array}$ & $\begin{array}{l}-0.001 \\
(0.021)\end{array}$ & $\begin{array}{l}0.004 \\
(0.021)\end{array}$ & $\begin{array}{l}-0.022 \\
(0.023)\end{array}$ & $\begin{array}{l}-0.014 \\
(0.022)\end{array}$ \\
\hline Asset share of government controlled banks & $\begin{array}{l}-0.003 * \\
(0.002) \\
\end{array}$ & $\begin{array}{l}-0.008^{* * * *} \\
(0.002) \\
\end{array}$ & $\begin{array}{l}-0.005^{* * *} \\
(0.002) \\
\end{array}$ & $\begin{array}{l}-0.003 \\
(0.003) \\
\end{array}$ & $\begin{array}{l}-0.002 \\
(0.003) \\
\end{array}$ & $\begin{array}{l}0.002 \\
(0.002) \\
\end{array}$ \\
\hline Asset share of foreign controlled banks & $\begin{array}{l}0.002 \\
(0.002) \\
\end{array}$ & $\begin{array}{l}0.005 * * * \\
(0.002) \\
\end{array}$ & $\begin{array}{l}0.004 * * \\
(0.002) \\
\end{array}$ & $\begin{array}{l}0.003 * * \\
(0.001) \\
\end{array}$ & $\begin{array}{l}0.002 \\
(0.002) \\
\end{array}$ & $\begin{array}{l}-0.001 \\
(0.002) \\
\end{array}$ \\
\hline Legal rights index & $\begin{array}{l}-0.005 \\
(0.018)\end{array}$ & $\begin{array}{l}-0.004 \\
(0.021)\end{array}$ & $\begin{array}{l}0.006 \\
(0.020)\end{array}$ & $\begin{array}{l}-0.023 \\
(0.017)\end{array}$ & $\begin{array}{l}0.000 \\
(0.020)\end{array}$ & $\begin{array}{l}0.000 \\
(0.018)\end{array}$ \\
\hline Political risk rating & $\begin{array}{l}-0.002 \\
(0.007) \\
\end{array}$ & $\begin{array}{l}0.003 \\
(0.008) \\
\end{array}$ & $\begin{array}{l}0.001 \\
(0.007) \\
\end{array}$ & $\begin{array}{l}-0.010 \\
(0.006) \\
\end{array}$ & $\begin{array}{l}-0.009 \\
(0.008) \\
\end{array}$ & $\begin{array}{l}-0.000 \\
(0.008) \\
\end{array}$ \\
\hline G2P transfers: open accounts & $\begin{array}{l}0.116 \\
(0.111) \\
\end{array}$ & $\begin{array}{l}0.038 \\
(0.091) \\
\end{array}$ & $\begin{array}{l}0.084 \\
(0.089)\end{array}$ & $\begin{array}{l}0.031 \\
(0.097)\end{array}$ & $\begin{array}{l}-0.292 * * * \\
(0.089)\end{array}$ & $\begin{array}{l}-0.266 * * * \\
(0.088)\end{array}$ \\
\hline Promoting savings, Savings scheme & $\begin{array}{l}0.287^{*} \\
(0.158) \\
\end{array}$ & $\begin{array}{l}0.057 \\
(0.101) \\
\end{array}$ & $\begin{array}{l}0.208 * * \\
(0.080)\end{array}$ & $\begin{array}{l}0.265^{* * * *} \\
(0.096) \\
\end{array}$ & $\begin{array}{l}-0.215^{* *} * \\
(0.106) \\
\end{array}$ & $\begin{array}{l}-0.431 * * * \\
(0.114)\end{array}$ \\
\hline Promoting savings, Tax incentive scheme & $\begin{array}{l}-0.094 \\
(0.139)\end{array}$ & $\begin{array}{l}-0.099 \\
(0.113)\end{array}$ & $\begin{array}{l}-0.057 \\
(0.094)\end{array}$ & $\begin{array}{l}-0.057 \\
(0.132)\end{array}$ & $\begin{array}{l}-0.269 * * * \\
(0.085)\end{array}$ & $\begin{array}{l}-0.082 \\
(0.133)\end{array}$ \\
\hline
\end{tabular}

The sample includes only unbanked adults. Each cell represents the estimation result of a separate regression of a perceived barrier to account ownership on the set of individual characteristics in Table 2, the log of GDP per capita, and a country characteristic. These account barriers are as follows. Too expensive refers to the respondents without an account that indicated "They are too expensive" as a reason. Lack of necessary documentation refers to the respondents without an account that indicated "You don't have the necessary documentation" as a reason. Too far away and no trust refers to the respondents without an account that indicated "Too far away" and "You don't trust them" as a reason, respectively. Finally, not enough money refers to the respondents without an account that indicated "Not enough money to use" as a reason. Note that respondent could give multiple reasons for not having an account. The exact definitions and data sources are in Table 2. Standard errors are in parentheses and are clustered at the country level. ***, **, and * denote significance at the $1 \%, 5 \%$, and $10 \%$ level, respectively. 
Figure 1: Ownership and use of formal accounts

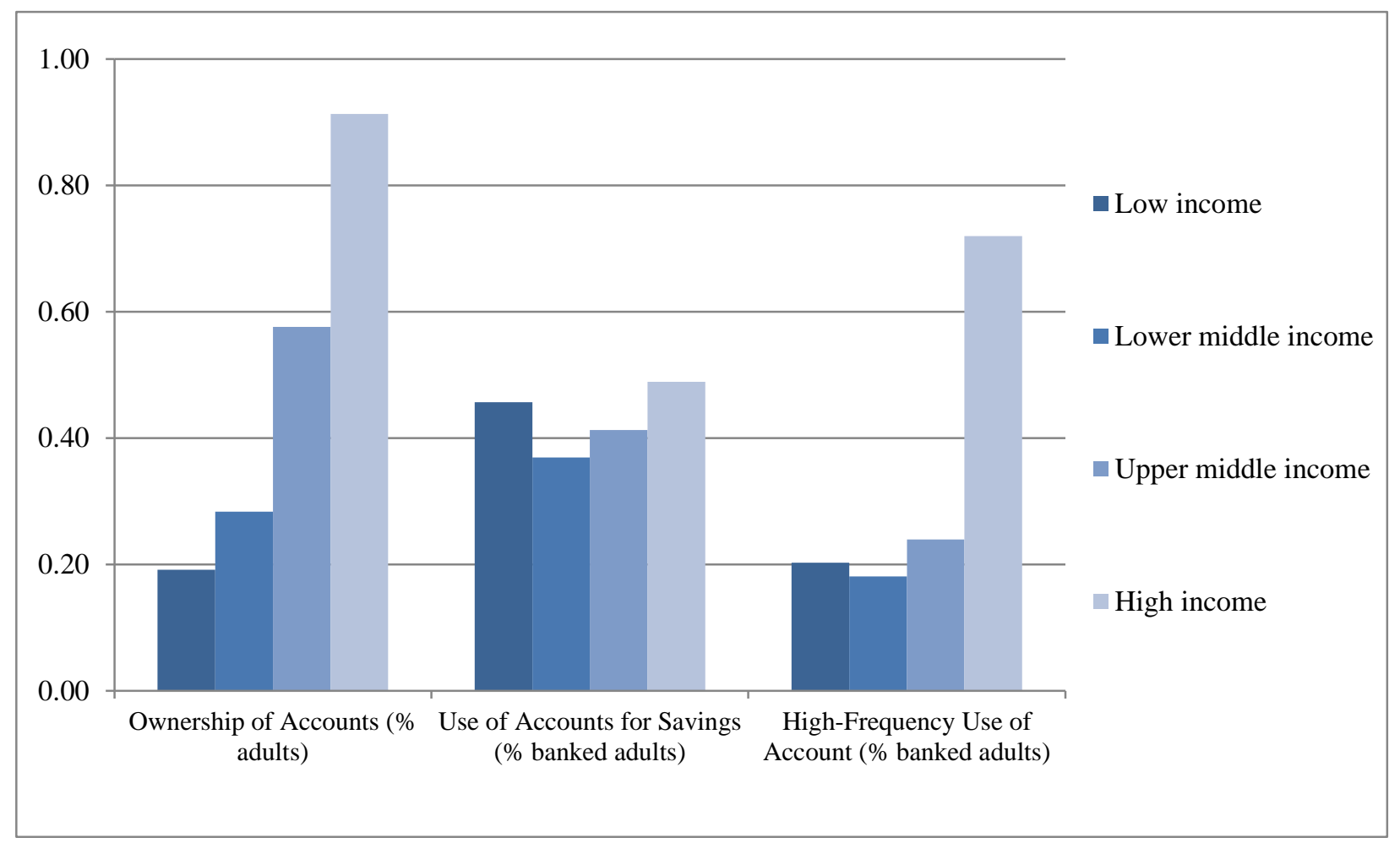

Source: Global Findex, 2011 